\title{
DA FORÇA DO GOVERNO ATUAL DA FRANÇA E DA NECESSIDADE DE APOIÁ-LO*
}

\author{
Benjamin Constant
}

momento atual é um dos mais importantes da Revolução. A ordem e a liberdade estão de um lado, a anarquia e o despotismo, do outro. Restam poucos momentos ainda para se pronunciar; é preciso se apressar em renunciar às lembranças e aos ódios, ou amanhã estes ódios serão substituídos por inúteis arrependimentos, aquelas lembranças por amargos remorsos.

Formei, sobre a necessidade de se aderir ao governo, algumas idéias que me pareceram úteis, e sobre esses primeiros passos na carreira constitucional, algumas reflexões que me pareceram tranquilizadoras.

Encontrar-se-ão, talvez, expressões severas sobre homens que merecem estima; mais suas intenções são puras e seus caracteres estimáveis, mais seus erros podem ser funestos.

É preciso que esses homens se aproximem do governo, e não o governo desses homens. Quando são eles que o seguem, trazem-lhe a honestidade e a moderação, mas quando é ele que o faz, dão-lhe vacilação e fraqueza.

O espírito de partido é o único a ganhar ao se julgar as instituições pelas pessoas, as operações pelos agentes, e ao se antecipar às medidas por uma censura, que freqüentemente só se torna justa por que foi prematura.

\footnotetext{
* Tradução de Josemar Machado de Oliveira - Doutorando em História Social-FFLCH/USP.
} 
Um defeito que caracteriza quase todos os que desempenharam um papel na Revolução, e sobretudo os vencidos após sua derrota, é o de sempre querer conduzir as coisas ao invés de segui-las. Olham seu triunfo como o alvo geral, e acreditam que o alvo não se poder atingir, visto que foram ultrapassados.

Não estando ligado a nenhum partido por qualquer interesse, desconhecido mesmo da maior parte dos indivíduos, nenhum motivo pessoal pôde dirigir meus julgamentos. Desejo ardentemente ver terminar a Revolução, porque doravante ela só pode ser funesta à liberdade; e é uma das minhas razões para desejar ardentemente também o fortalecimento da República, à qual, de resto, me parece se ligar tudo o que há de nobre e de grande nos destinos humanos.

Esteve longe de meu pensamento escrever contra qualquer gênero de governo, convidar qualquer Estado monárquico a renunciar à Realeza, qualquer Aristocracia a adotar formas democráticas; mas acredito no dever rigoroso de todo amigo da humanidade, de exortar uma nação que se governa por seus representantes a permanecer fiel ao governo representativo.

A experiência das revoluções, o amor da ordem e da paz obrigam-nos a respeitar ou a tomar cuidado com as instituições de todos os povos; mas todos os sentimentos reunidos exigem de nós o mesmo respeito, os mesmos cuidados para com as instituições republicanas. 


\section{CAPÍTULO PRIMEIRO}

\section{Dos homens que atacaram a Convenção}

Há, em todas as sociedades, uma classe de homens escrupulosos, detalhistas e descontentes, que possuem talentos, honestidade, uma memória implacável e uma vaidade sem limites. Esses homens não são perigosos para os governos, mas são inoportunos. Não o atacam, mas o contestam, o importunam, o fatigam. Colocando um preço igual em todas as suas idéias, voltam à carga, com uma igual insistência, sobre as maiores questões e sobre as menores queixas. A importância que dão às coisas não nasce das coisas em si mesmas, nasce deles; uma opinião parece-lhes consagrada uma vez tomada sua defesa, e como apenas vêem a salvação do Estado em sua consideração individual, impõem-se um dever de perseverança que, freqüentemente aplicado aos objetos, seja minuciosos, seja irreparáveis, tem a desvantagem, alternativamente, de empregar sua influência, ou de torná-la incômoda, de exasperar os que governam, ou de acostumá-los à censura, acabando mesmo por reunir esse duplo inconveniente.

Esses homens, entretanto, são úteis em um governo velho e abusivo. Eles o mantém em um tipo de inquietude salutar, que impede o excesso dos abusos, perturbando-lhe o usufruto. De resto, suas forças são proporcionais a seu objeto. Moderam a ação irregular da força empregada, opondo-lhe fracos obstáculos.

Eles são, ao contrário, não somente inúteis, mas essencialmente perigosos, nas revoluções, e nos governos nascentes. Eles nada podem contra uma impulsão irresistível; e, entretanto, pelos entraves que nela colocam, fazem acreditar na necessidade de uma velocidade adicional. A inquietude que inspiram, juntando-se às paixões violentas criadas pelos perigos e pelos esforços extraordinários, torna-se facilmente furor. Suas manobras, que em nada perturbam a segurança de um governo estabelecido, tomam, como uma consequiência natural da desconfiança inseparável dos homens e das instituições novas, a aparência de complôs: os governos confundem manobras com ataques, floretes com punhaladas, e aqueles que somente querem brilhar com aqueles que têm o propósito de prejudicar. 
Deixar falar é o que os homens no poder aprendem com mais dificuldade, e, contudo, é o que lhes é mais necessário saber. Ora, um murmúrio contínuo de vozes, de insinuações e de amargura, coloca o obstáculo mais invencível à aquisição dessa ciência.

Os homens dos quais estou falando são impacientes sobretudo por um tipo de raciocínio, exato na aparência e falso no fato, com a ajuda do qual desconhecem sempre as conseqüências de tudo o que fazem: mediram matematicamente o afastamento que é preciso ter de um arsenal de pólvora para não fazê-lo explodir; vão, sem necessidade, sem utilidade, unicamente pela honra de sua teoria, colocar-se com os materiais inflamáveis precisamente sobre a linha que traçaram: o fogo pega na pólvora, vós sois derrubados, machucados; mas eles vos provam com toda a lógica do mundo que o arsenal não deveria ter explodido. Ah! meçais menos e afastai-vos; importa-nos pouco admirar vossos cálculos e muito prevenir a explosão.

Esses homens têm ainda o singular infortúnio de não perceber nenhuma das mudanças trazidas pelos próprios acontecimentos dos quais se queixam, nas opiniões, nos interesses, nas coisas e nas pessoas. Não vêem que as Revoluções fazem desaparecer os matizes, que uma torrente tudo nivela. São como antigos soldados, que, tendo feito em um país uma guerra de posição, querem continuar essa guerra e retomar essas posições, depois que o terreno foi modificado por um terremoto.

Esses homens desempenharam um pequeno papel e fizeram um grande mal na última época da Revolução. Eles aí chegaram com todas as suas pequenas finuras, todas as suas gentilezas irônicas, todo esse soar de gracejos e de alusões, todas essas graças espirituosas que fizeram seu sucesso no antigo regime, e quiseram lutar, com semelhantes armas, contra homens novos, violentos, enérgicos, que aprenderam a desafiar mais que o perigo, e cujo caráter tinha sido formado pela mais terrível educação revolucionária.

Mais de uma vez, uma insinuação amarga retardou o benefício de um mau Decreto, uma alusão ofensiva provocou uma medida injusta, uma imprudente lembrança tornou homens já arrependidos implacáveis com suas culpas, pois o desespero dos culpados é bem diferente dos remorsos. 
Esses homens ofereceram, desde o 1 de Prairial [20 de maio de 1795] até o 13 de Vendemiário [5 de outubro de 1795], um espetáculo verdadeiramente único, e no qual não se pode acreditar se dele não se foi testemunha.

Aqueles que, nessa época, achavam-se revestidos de todos os poderes, envergonhados de ter por muito tempo suportado a mais execrável tirania, guardavam o poder quase a contragosto e como uma salvaguarda, e buscavam, por todos os meios, por todas as declarações, por todas as demonstrações imagináveis, obter a indulgência de uma nação esmagada, desencorajada, desarmada, sem união, sem força, que, seis meses antes, teria rendido graças ao Despotismo, se, reforçando suas cadeias, tivesse derrubado os cadafalsos.

Que fizeram esses homens, que, em nome dessa nação, proclamaram-se os órgãos da opinião pública? Declararam-se inexoráveis em sua fraqueza, implacáveis em sua impotência, e recusaram-se obstinadamente a conceder o perdão, o que unicamente podia salvar sua pátria, àqueles que deixaram donos de seu destino, e que forçavam assim a tomar pela violência da impunidade o que teriam consentido em merecer.

Eles culpavam amargamente o governo de ter feito o mal, e não queriam reconhecê-lo como capaz de fazer o bem. Exigiam à altos brados reparações, sem prometer, ou antes recusando de antemão toda indulgência. Acusavam os homens no poder de ferocidade demoníaca, e os provocavam como se tivessem a paciência dos anjos. Aplicavam-se em confundir os inocentes com os culpados, os fracos com os criminosos. As prisões, a proscrição, tudo o que tinha evidentemente impedido quase a metade da Convenção de ter tomado parte mesmo passiva na tirania, o zelo com o qual, desde sua libertação, ela expulsava de seu seio, com uma precipitação algumas vezes irregular, aqueles de seus membros considerados culpados, não desarmava em nada a severidade de seus censores. Dir-se-ia que era para eles um triunfo demonstrar que, entre os 750 homens, que dispunham de suas fortunas e de suas vidas, não se encontrava nenhum honesto. Esforçavam-se em transformar os arrependimentos em pavor, os remorsos em furor, e a seguir espantavam-se que esse furor e esse pavor não levavam sempre a medidas sábias e suaves. 
Desde o 1 de Prairial, a maioria da Convenção, à qual se pode hoje fazer justiça, sem parecer suspeito, pois ela cessou de ser, e ninguém, graças aos céus, herdou seu vastíssimo poder, a maioria, digo eu, da Convenção, esclarecida por longas calamidades, tinha evidentemente intenções puras. As tentativas ferozes dos Terroristas tinham-lhe inspirado um tal horror e o sentimento dos seus erros uma tal moderação que seis meses de ultrajes e uma vitória não puderam felizmente nem faze-la esquecer de um, nem desviá-la de outra, tanto estava curvada sob o peso das lembranças. A acolhida que ela deu a todas as idéias sãs que continha o projeto da Comissão dos onze, o entusiasmo com o qual aplaudiu verdades que eram para ela recriminações mais ou menos diretas, sua pressa em limitar seu próprio poder, não deixam nenhuma dúvida a esse respeito. Poder-se-me-á objetar que essas intenções que elogio, que essa moderação que admiro, eram o fruto tardio de dois anos horríveis e de fraquezas inexpiáveis para não dizer mais nada; talvez. Mas não era necessário encorajá-la nessa conversão inesperada? Não era preciso se beneficiar da razão que havia adquirido, para receber dela uma constituição estável, da qual a França tinha uma tão grande necessidade? Do fato dos homens poderosos terem sido muito tempo fracos ou mesmo culpáveis, resulta disso, se eles têm em mão a sorte do império, que seja preciso pôlos a todo momento entre suas intenções e sua vaidade, seu interesse e seu dever?

É elogiando os homens que os empurramos em direção ao bem; é mostrandose persuadido que eles não podem se recusar à ações honestas, que os forçamos a essas ações. O céu deu ao próprio crime um tipo de pudor, que não ousa desmentir as virtudes que lhe atribuímos e que lhe serve de consciência. Quando ele é poderoso, longe de desmascará-lo, é preciso emprestar-lhe uma máscara; disfarçando sua torpeza ela é diminuída, porque ela não é com frequiência mais que o fruto da idéia que a concebeu, e assim reage sobre si mesma. Vi mais de uma vez a generosidade, a humanidade, todas as virtudes que, em uma palavra, pertencem a grandeza, e prestam-se à ostentação, nascer de um elogio a corações já corrompidos; eles não ousavam repelir o elogio, e recebendo-o sentiam-se comprometidos. 
Qual era, pois, o alvo dos que dirigem a opinião, quando pareciam assumir a tarefa de mostrar à assembléia que ela não podia nada reparar, que não existia para ela, no bem, nenhuma segurança, que seu interesse era o mal, que no mal estava seu asilo?

O que era esse delírio inexplicável, que os levava a repetir de todas as maneiras aos Convencionais, que, uma vez privados de seu poder, ocupar-se-iam de seu castigo, e a seguir espantar-se de que demoravam a deixar o poder? Eles lhes demonstravam, com a evidência mais desastrosa, que o poder era sua única proteção, acusando-os depois de um crime por querer guardar esse poder!

Temiam, diziam eles, o restabelecimento do terror. Era preciso pois convencer a Convenção que o terror tinha sido, mesmo para ela, perigoso; trabalhavam, ao contrário, para persuadi-la que o terror era-lhe necessário.

Freqüentemente, ao contemplar esse estranho frenesi, perguntei-me se o intuito desses homens era sacrificar os tristes restos de uma geração já dizimada por Robespierre.

Freqüentemente, ao escutar esses recursos ultrajantes, pronunciados à barra de uma assembléia ardente e tumultuosa, perguntei-me se o espírito dos Decêmviros impelia os oradores, sem que o soubessem, contra uma Convenção irritável, para obter, com o choque de tantas paixões ofendidas, uma vingança digna de suas almas.

Não, não era para um fim atroz que esses insensatos colocavam assim sua infortunada pátria em perigo. A vaidade extraviava-os, o desejo pueril de fazer efeito, o mesquinho triunfo de pronunciar em público frases, que tinham cessado de ser corajosas, desde que se pudesse repeti-las.

Tantas e tão miseráveis causas decidem das revoluções dos impérios e dos destinos da humanidade! Se a Convenção não tivesse sido mais esclarecida que esses homens sobre sua própria fraqueza, se ela tivesse podido considerá-los tão temíveis quanto ousavam se vangloriar, nenhuma dúvida que o terror, que eles provocavam, com uma tão obstinada imprudência, não tivesse ensangüentado de novo o solo devastado dessa terra infeliz! E certamente, não é um pequeno mérito dessa assembléia de ter marchado em direção à liberdade, quando a empurravam para o caminho da tirania, de ter respeitado as barreiras que se havia posto, quando, por sobre essas barreiras, 
ergueram-se baterias para abatê-la, e de ter sabido permanecer constitucional e moderada, quando a forçaram a voltar a ser revolucionária e todo-poderosa. 


\section{CAPÍTULO II}

\section{Da força que as atuais circunstâncias dão ao Governo}

Esses erros deploráveis, que estão ainda muito perto de nós para apenas excitar o espanto, provinham sobretudo do fato de que se desconhecia a força do Governo e de que se tomava o arrependimento por fraqueza e o desejo de reparar por impossibilidade de ferir.

Esse equívoco foi geral a partir da queda de Robespierre: a quantos perigos ele não expôs a França! A experiência do 13 de Vendemiário pareceu tê-lo dissipado: mas quantas vezes nos últimos seis anos não vimos a experiência não ser nada para a conduta dos homens? A Revolução parece tê-los dotado da mais funesta memória sobre o que é irreparável, e tê-los tocado com uma cegueira não menos funesta, sobre o que pode causar novos males. Caminhando de costas em direção ao futuro, somente contemplam o passado: suas lembranças são todas ressentimentos, e do esquecimento têm toda imprevidência.

É, pois, útil provar que o Governo é forte por si mesmo, que ele jamais pode ser atacado com vantagem, que jamais a chance dos agressores pode ser tão favorável como foi em Vendemiário, e que a vitória da Convenção foi bem menos uma sequiência dos erros das seções, erros que novos descontentes se vangloriam de evitar, que uma consequiência do estado atual e durável da República.

Essa República tem a seu favor uma primeira vantagem, à qual não se dá o devido reconhecimento, que é ser o que há de mais estável. Uma mulher de espírito dizia, em elogio à vida, ser já não é o bastante? É para os Governos sobretudo que essa palavra é verdadeira.

A metade, pelo menos, dos interesses da França está ligada, no presente, à República. Se as disposições dos emigrados fossem mais conhecidas, se as conseqüências inevitáveis de uma subversão realista, que não poderia deixar de permitir o triunfo dessa casta, fossem melhor apreciadas, ver-se-ia ligar ainda, ao Governo que dela preserva, mais de sete oitavos da outra metade. Assim, a República tem a seu favor ser, mais os interesses de uma multidão de homens, e esses formando a parte mais ardente, a mais entusiasta, de uma grande nação. 
Aqueles que querem derrubar a República são curiosamente vítimas das palavras. Viram que uma Revolução foi uma coisa terrível e funesta, e concluem que o que chamam uma contra-revolução seria um evento feliz. Não se dão conta de que essa contra-revolução apenas seria ela mesma uma nova revolução.

Os interesses que ligam à República são de um gênero bem mais profundo, bem mais íntimo, que aqueles que ligavam ao antigo regime. Os partidários deste último, no começo dessas tormentas, não previam seguramente todos os males que provariam, e que, em grande parte, foram a consequiência de sua imprudente oposição. Não defendiam mais que uma porção de sua fortuna, seus preconceitos e sua vaidade. Que calamidades, entretanto, não desencadeou essa luta desigual!

Aqueles que ligaram sua sorte à República têm a defender, no lugar de preconceitos, o que vêem como princípios, no lugar de interesses pessoais, o que é para eles uma religião, no lugar da vaidade, um orgulho, seja, mas um orgulho mais profundo, mais viril, mais inerente à sua natureza, mais caro ao seu coração, pois é para eles a reabilitação de sua classe, o fruto de uma conquista, a desculpa de sua conduta, e a garantia de sua segurança. Eles têm a defender sua fortuna e além disso sua vida. Qual não seria o abalo de uma semelhante reviravolta?

Ora, que se recuse a comprar mesmo a liberdade, por meio de convulsões, da anarquia e do massacre, eu o concebo. Mas que se dê, com o intuito bem menos inebriante de mudar a forma de um governo qualquer, permissão às convulsões, ao massacre, à anarquia, eu não posso concebê-lo.

Há sem dúvida descontentes: mas é um erro tomar todos os descontentes por inimigos. Crê-se em demasia que aqueles que encontram alguma coisa de incômodo em sua habitação estão prontos à derrubá-la. O homem tem o humor frondeuse mais que destrutivo. Os interesses da maior parte daqueles que se imaginam estar descontentes, estão ligados, algumas vezes sem que se dêem conta, ao governo; no instante do perigo, o instinto desse interesse se dá a conhecer, e quando a luta começa, arrasta, não somente todos os homens nulos, mas aqueles mesmos que murmuram, excetuada precisamente a fração que ataca. 
Essa vantagem de existir, imensa em todos os tempos, é bem aumentada pelas circunstâncias presentes.

À medida que um governo envelhece, a massa se neutraliza. Ele toma uma existência à parte; seus meios se separam dos meios comuns, e por isso mesmo tornamse limitados. Seus inimigos têm também seus meios, e leva a melhor quem é o mais forte. O povo está no meio, indiferente, na ignorância da luta, até o momento em que ela explode. Por ela fica informado, e nesse momento, o governo, obrigado a lhe prestar conta de sua imobilidade, vê-se reduzido ao estado de um partido que combate corpo a corpo um partido contrário.

$\mathrm{Na}$ França é tudo diferente. O governo não se separou ainda ostensivamente do povo. A massa inerte, cujo peso acaba sempre por conduzir ao fundo, agitada ainda pela fermentação revolucionária, convulsiona até a superfície. O governo sabe que tem inimigos, e os conhece: o povo sabe que existem partidos que querem derrubar o sistema que existe. O choque apenas se prepara, e já ele é obrigado a se pronunciar: e não pode deixar de fazê-lo, em favor do partido, que, com a vantagem exclusiva de ter um objetivo conhecido, reúne as tropas e os tesouros. O povo sabe o que o governo quer manter. Ele não sabe o que querem reedificar os descontentes, que só lhe propõem destruir.

Se todos os governos estivessem seguros de estar ameaçados (e o da França, pela natureza das coisas, terá por muito tempo ainda essa certeza), e se forçassem o povo sempre a se declarar antes do ataque, nenhuma insurreição teria sucesso.

Quando do caso das seções, não existiam todas essas vantagens. Não havia governo. Aqueles que tinham em mão a autoridade convinham eles mesmos que seu poder era provisório: não estava em questão manter-se em um estado estável, mas caminhar para um fim. Ora quando se trata de caminhar, o poder perde uma de suas mais belas prerrogativas, aquela de oferecer exclusivamente o repouso. Havia um ponto de contestação, sobre o qual o povo era, por seus próprios administradores, chamado a pronunciar-se. Podia declarar-se contra os governantes, sem ser contra o governo. Podia não ver mais que homens, não uma constituição à derrubar. Podia tomar o que lhe propunham os secionários por uma substituição, não por uma revo- 
lução. Não tinha um objeto presente para defender ou atacar, mas uma escolha a fazer para o futuro. Não se lhe pedia uma revolta, mas uma decisão. Acreditava preferir, e não destruir.

Aproximeis essas circunstâncias daquelas em que nos encontramos atualmente, e sentireis que desvantagem imensa aqueles que quisessem conspirar hoje teriam, comparados aos homens do Vendemiário, vos vistes, contudo, o sucesso destes últimos.

Observeis de resto que os descontentes, divididos por opiniões, não se acordam, não podem acordar-se; que há entre eles uma facção, que é a inimiga mais perigosa de todas as outras; que ao primeiro barulho de uma insurreição, todos aqueles que não estavam ao corrente do segredo, mesmo se quisessem juntar-se aos insurretos, não poderiam, ignorando qual facção se insurge; que esta não ousaria se pronunciar desde a origem, com medo de alienar cinco ou seis de seus rivais; e que, com sorte, a maioria dos descontentes que se teriam levantado ao rumor do ataque, se encontrariam no exército do Governo, na ausência de saber onde está o campo dos inimigos e de distinguir seu estandarte.

Ora, haverá desses homens, reunidos a contragosto à autoridade, como os jovens convocados, que se alistam lamentando-se e que combatem com heroísmo.

Uma segunda vantagem do Governo atual é a de estar decidido a permanecer. A maioria dos governos são suicidas: concordam em se modificar, hesitam, capitulam e tudo está perdido.

O governo da França quer existir na forma em que se encontra hoje. Os indivíduos que o compõem estão ligados à sua obra, por todos os interesses reunidos, e dando aos meios constitucionais e doces uma justa preferência, nunca recusarão nenhum meio proporcional ao perigo.

Poder-se-á acusá-los de um crime. Poder-se-á opor-lhes princípios abstratos e dizer que uma consequiência da Soberania do Povo, é que, a menos que sua vontade seja bem claramente exprimida, um Governo não tem o direito de defender sua existência. Os mesmos homens - que com razão elogiavam os governos estrangeiros por se oporem às Revoluções, que são sempre um grande mal- exigiriam natural- 
mente do governo da França que favorecesse sua subversão, e que sua única ocupação fosse um recenseamento perpétuo dos votos, a favor ou contra a República.

Ouvi ser dirigida aos homens que governam a divertida reprovação de parcialidade, e como aqueles que o faziam, tinham a intenção de confundir a imparcialidade com a justiça, não se descobria, ao primeiro olhar, o absurdo dessa reprovação.

A justiça é um dever dos governantes, a imparcialidade seria uma loucura e um crime. Para fazer funcionar uma instituição, é preciso que um homem seja parcial para com a instituição. Não é preciso que, pirroniano político, tenha que recolher as dúvidas, pesar as probabilidades, e pedir sem cessar à maioria se ela persiste em preferir a forma atual. O espírito do homem sendo versátil, é preciso que as instituições sejam estáveis. É preciso manter a maioria supondo-a invariável. É preciso lembrar-lhe o que ela quis, ensinar-lhe o que ela quer, fazendo-a encontrar a felicidade e o repouso sob as leis. Quando não houver contra os inimigos da Convenção, contra aqueles que se queria colocar à testa da nova Convenção, não mais que essa imparcialidade meritória entre todas as formas de governo, e a certeza que eles - escrupulosos a expensas de sua pátria - teriam novamente colocado em dúvida o que deveria terminar seis anos de infelicidades; apenas isso seria o bastante para os rejeitar, e somente isso já devia bastar, para resolver a muito famosa questão dos Dois Terços.

Longe de nós o piloto incerto, que, ainda abalado por um mar proceloso, mas em face do porto, pede à sua tripulação se por acaso não gostaria de recomeçar seu percurso. Longe de nós o general, que, quando seu exército está em batalha, e que o inimigo avança, propõe um escrutínio secreto, para saber se a maioria dos soldados, modificada pela chegada de algum novo recruta, não quer agora se submeter ou se retirar.

O povo se pronuncia por meio de fatos. No 14 de Julho, ele se pronunciou pela liberdade, no 10 de Agosto pela República, no 9 de Termidor e no 4 de Prairial contra a anarquia; eis seu voto. Livrai-nos de vossas dúvidas, não fatigai-nos mais com vosso ceticismo, ajudai-nos a consolidar a liberdade, a fazer florescer a República, a esmagar a anarquia, ou fechai-vos nas escolas, fazei-as retumbar com vossos argumentos, embriagai-vos de vossas abstrações, e não venhais, sobretudo, perturbar jamais nossas realidades. 
Muitos homens me disseram: pode-se ser um bom cidadão, não acreditar na possibilidade da República, e se submeter às suas leis. Isso é verdade: a Deus não agrada que eu transforme a hesitação em perversidade. Eu não quero, inquisidor republicano, fazer um crime de uma incerteza que é impossível a certos espíritos não possuir. O Governo deve proteção a todos, e as opiniões não são de nenhuma jurisdição humana.

Mas seguramente conviremos que os bons cidadãos desse gênero não são apropriados para fazer funcionar uma instituição, que lhes parece inexecutável.

Os maiores meios do homem estão em sua convicção. O entusiasmo que promete a vitória, a assegura. Não se melhora senão o que se quer e quando se espera que tenha duração. Resigna-se a fazer esforços se sua inutilidade é previsível: mas a resignação, por sua natureza, diminui pela metade as forças. Quando não se tem a responsabilidade de sua opinião, age-se com consciência, mas sem zelo. É preciso crer naquilo que se deve fazer progredir.

Existe, enfim, para o governo francês, um terceiro e terrível recurso, que ele rejeitará sempre nos momentos de calma, que a todos fará estremecer ao utilizá-lo e sobre o qual acreditaria dever guardar silêncio, se pela salvação pública não fosse preciso, enfim, olhá-lo uma vez fixamente. Até o presente diligenciou-se em fazer ressaltar seu horror, o que foi fácil, sem desdenhar em apreciar sua extensão, o que, pelo menos, foi também importante.

Vistes alguma vez, numa batalha, uma falange espessa de soldados, cerrados um contra o outro, avançando de maneira que a vista não vá além da primeira linha? Não parecem querer combater senão com as armas que têm na mão; não se tem outra preocupação que rechaçar o choque com o qual ameaçam. De repente param, fazem um movimento inesperado, abrem-se: uma artilharia formidável faz-se ver, e vomita sobre o inimigo pálido o espanto e a morte.

Os terroristas são essa artilharia do governo, sempre escondida, mas sempre temível, e que, todas as vezes que ele for forçado a empregá-la, reduzirá a pó seus adversários.

Esses homens, ou antes esses seres, de uma espécie desconhecida até os nossos dias, fenômenos criados pela Revolução, ao mesmo tempo inconstantes e ferozes, irritáveis e endurecidos, impiedosos e apaixonados, que reúnem o que até o presente 
parecia contraditório, a coragem e a crueldade, o amor à liberdade e a sede de despotismo, a altivez que engrandece e o crime que degrada, esses tigres, dotados por não sei qual espantoso milagre de uma só parte da inteligência humana, com a qual aprenderam a conceber uma única idéia e a reconhecer uma só palavra de união, essa raça nova, que parece saída dos abismos para libertar e devastar a terra, para quebrar todos os jugos e todas as leis, para fazer triunfar a liberdade e para desonrá-la, para esmagar tanto aos que a atacam quanto aos que a defendem, essas potências cegas de destruição e de morte, colocaram ao retorno da Realeza um obstáculo que ela jamais superará.

Eles poderiam destruir o governo, mas não podem suportar de nenhum maneira que seja destruído por mãos estrangeiras; são contra o governo, quando este não é atacado, porque são contra tudo o que pesa sobre suas indóceis cabeças, contra tudo o que os impede de satisfazer sua horrível sede de sangue; mas estarão com ele desde que seja atacado, porque sentem que os agressores são ainda mais seus inimigos do que os da constituição estabelecida; e eles não têm essa imbecilidade, caráter distintivo de um outro partido, que, no seu despeito contra os homens que o protegem, depois de tê-lo vencido, sempre tolerou e toleraria ainda que se os imolasse, ainda que devêssemos atacá-lo e passar sobre seus cadáveres.

Enquanto o governo estiver tranquiilo, intimidará os terroristas; sabe que seu triunfo seria sua perda, não ignora que, mesmo se apossando de seu sistema, não poderia se manter. Esse sistema é somente destrutivo; no momento em que, em meio às suas devastações, não lhe resta mais nada para destruir, deve se voltar contra seus autores, como os animais que - atingidos pela raiva, depois de ter dilacerado tudo o que encontram - acabam por se dilacerar a si mesmos.

Mas se o governo se acreditar em perigo, se uma facção obstinada chegar a forçar suas linhas, se, a posição perigosa com uma coragem que é bem insensato desconhecer, ele ousou tomar entre os partidários do terror e aqueles da realeza, se visse pronto a ser imolado por esses últimos, sem dúvida recuaria para se juntar aos primeiros. Vendo-se empurrado para esses antros sangrentos, deles sairia, com seus ferozes habitantes, para se lançar sobre os agressores culpados, aos quais então unicamente caberia o crime, sendo responsáveis de todas as calamidades da Pátria, de todo o sangue que seria derramado. 
A vitória não seria duvidosa: mas quem pode calcular as conseqüências? Quem pode se vangloriar de que o governo seria sempre bastante forte para conter seus aliados vencedores? Quem pode prever onde iriam deter-se os excessos de uma conquista? Quem poderá prever as desgraças, que produziriam tantos motivos novos, tantas lembranças, humilhações, furores! Os terroristas, déspotas quase sem combates, sem ressentimentos, sem ultrajes a vingar, foram atrozes! Como não seriam hoje! Quem ousaria encarar fixamente essa chance horrível? Quem, mesmo com as probabilidades do sucesso, ousaria afrontá-la? Não há expressão forte o bastante para exprimir o horror que ele mereceria, e os nomes que pronunciamos com estremecimento seriam equivalentes por seu nome.

Não é - deve-se apressar em proclamar essa tranqüilizadora verdade- que a imensa maioria dos governantes não esteja decidida a tudo arriscar, a qualquer momento, para se opor ao retorno do terror. É doce fazer justiça àqueles que as paixões se comprazem em menosprezar. Eu vi, depois da jornada do Vendemiário, quando todos os monstros foram desencadeados, homens, que um ódio absurdo chamava então de terroristas, porque defendiam a República-como os Montanheses nomearam realistas os que foram postos fora da lei porque resistiam à anarquia - eu vi, digo, esses homens gemendo sobre as conseqüências de uma vitória, que se lhes fizera necessária, retomar, pelos mais perigosos esforços, a posição média que haviam sido forçados a abandonar, e em meio mesmo às proscrições secionárias, novamente afrontar as proscrições terroristas. Graças lhes sejam rendidas: sozinhos esmagaram esse terror renascente, que provocava um partido insensato, e que queria um partido atroz.

Mas quem nos responderia pelos efeitos de uma nova tentativa? Quem poderia se vangloriar, que tantas imprudências reiteradas, não recolheriam nem sequer uma vez seu deplorável salário?

Homens de todos os sistemas! Reconheçais, enfim, que não tendes mais que um interesse; guardai-vos de incomodar o gênio tutelar da França, que, desde o 9 do Termidor, arrancou-a de perigos tão numerosos; cedais à força das coisas, quaisquer que sejam vossas opiniões e vossos hábitos, e juntai-vos a um governo, que vos oferece a paz e a liberdade, e que não pode desmoronar, sem vos enterrar sob suas ruínas. 


\section{CAPÍTULO III}

\section{Dos males atuais da França}

Se, entretanto, os males de todo gênero que a França ainda experimenta fossem o resultado necessário dessa forma de governo, demonstrar sua estabilidade não faria redobrar esses males destruindo até a esperança de vê-los acabar? É preciso, pois, contemplar atentamente o triste espetáculo, e investigar se eles se ligam ao governo republicano.

A guerra exterior exige um consumo imenso de homens e tesouros: a Vendéia devora a população das mais belas províncias; o comércio está destruído; a marinha não existe mais; assignats sem valor inundam a República; a falta de numerário força o governo aos empréstimos, às requisições, às medidas destrutivas da liberdade como a da indústria individual; o descontentamento interior obriga a uma vigilância inquisitorial e a precauções vexatórias.

Não se pode dizer que aligeirei esse quadro aflitivo: mas sendo ele o resultado da revolução, que nos conduziu à república, poderíamos nos apegar a essa instituição por si mesma? A República é um fim, a revolução foi uma rota; é tempo de desviar nossos olhares dessa rota para ver, enfim, aonde chegamos.

O restabelecimento da Realeza acabaria com as vicissitudes da França? Tal é a única questão que nos interessa.

Há dois tipos de Realeza, entre as quais as opiniões podem ser separadas; uma é uma religião, a outra um cálculo; uma tem mais amigos, talvez, mas fracos, indecisos, divididos, especulativos; a outra tem partidários ativos, ardentes, unidos, fanáticos. Uma, pensando bem, é a Realeza mitigada, ou constitucional; a outra, a Realeza absoluta ou o antigo regime.

Nem uma nem outra dessas Realezas faria cessar a guerra. Não se pode mais acreditar que as potências tenham por fim único ou mesmo por fim principal, a reintegração da Monarquia. Elas traíram seu segredo. O novo Rei, qualquer que fosse, iria ter tanta força quanto o Diretório, o que não se pode esperar da Realeza constitucional, e o que me pareceria difícil, mesmo para a Realeza fanatizante, o novo Rei, afirmo, não obteria uma paz mais honrosa que a República. As potências reco- 
brariam em coragem, o que seria bem autorizado pelas conseqüências inevitáveis, e desorganizadoras de uma nova Revolução, e pelo desprezo, que não poderia deixar de lhes inspirar a inconseqüência do povo francês. Elas exigiriam indenizações, talvez o desmembramento da França; o que o interesse evidente de sua causa não pôde impedi-las de exigir, exigiriam elas menos quando esse interesse não mais existisse? Não puderam se decidir pela dissimulação momentânea de suas esperanças, a tornar o sucesso menos inverossímil; estariam elas mais dispostas a pagar com um sacrifício real uma vitória já obtida? Somos bem menos liberais quando recompensamos do que quando compramos. Unicamente a necessidade da paz pôde engajar várias dentre elas, e poderá engajar as demais, a renunciar às suas pretensões; e só o fortalecimento do governo pode completar e decidir essa necessidade. Assim, para a França, o restabelecimento da Realeza tornaria a paz ou mais difícil ou mais vergonhosa.

Quanto ao comércio, quanto à marinha, sabemos que estas duas fontes de prosperidade somente se restabelecem lentamente. Um rei não traria à França nenhum meio de reanimar a um ou a outra; o entusiasmo da liberdade pode fazer milagres; mas a Realeza não tem como faze-los, e não seria seguramente frente à marinha da monarquia, que a da Inglaterra perderia sua superioridade. A forma de governo apenas influi sobre o comércio pela liberdade que lhe deixa: seu crescimento está ligado ao exercício individual, e ilimitado, da indústria. Como acreditar que o eterno inimigo do nome francês poderia favorecer o comércio da França, à condição que o trono fosse restaurado, que devolveria à monarquia as colônias que tomou da República, e que Mr. Pitt agiria desinteressado, a partir do momento em que os franceses se tornassem Realistas?

O crédito, cuja ausência é um tão cruel flagelo, renasceria sob a Realeza? Um rei constitucional inspiraria mais confiança que o Diretório? Seu poder pareceria melhor estabelecido? Uma prova a mais de instabilidade faria acreditar em sua estabilidade? Forçado a renunciar a vários dos recursos existentes, por quais recursos novos os substituiria? Se a Realeza absoluta achasse alguns meios passageiros e precários, eles seriam fundados sobre a invasão de todas as propriedades, que aumentaram por causa da revolução, ou mesmo, que, atravessando-a intactas, contraíram, 
aos olhos do antigo regime, uma mancha indelével. Os assignats seriam talvez anulados, como provenientes de uma autoridade ilegítima, e como estando hipotecados sobre bens que seriam devolvidos a seus antigos possuidores. Mas o desaparecimento desse símbolo aviltado não restabeleceria a abundância do numerário. Um governo da Realeza estaria reduzido aos mesmos meios pelos quais se censura a República: os empréstimos forçados, as requisições, renovar-se-iam em nome de um rei, com tanto mais força porquanto não teria, como o governo atual, a responsabilidade do passado. Não seria obrigado a nenhuma deferência, porque lançaria suas vexações sobre a República, que o precedeu. Ela somente cavou, dir-se-ia, o abismo no qual nos encontramos. O interesse do Diretório é diminuir os males causados pela revolução: o interesse de um rei seria faze-los ressaltar. Um se esforça para fazer com que se encontre no presente a desculpa do passado: o outro encontraria no passado a desculpa do presente. Um quer reparar por todos os meios possíveis; o outro, sempre falando de indulgência, quereria punir indiretamente. Um quer inspirar a esperança e o esquecimento; o outro quereria impressionar com lembranças e medo.

Enfim, o restabelecimento de uma das duas Realezas colocaria um fim nos descontentamentos interiores e uniria todos os partidos?

A Realeza constitucional teria por adversários todos os republicanos, mais todos os inimigos da República, fora o número muito pequeno dos realistas moderados. O pretendente atual ao trono empenha-se em revelar seu desdém por toda outra forma de governo que não a antiga monarquia ${ }^{\mathrm{A}}$. Seus partidários, os Chouans, os Vendéens,

\footnotetext{
${ }^{\text {A }}$ Os magistrados emigrados acabaram de publicar uma obra intitulada Desenvolvimento dos princípios fundamentais da Monarquia Francesa. Esta obra foi redigida por ordem dos Príncipes, que, depois de ter suspendido várias vezes sua publicação, enfim permitiram a que apareceu (páginas XXVI e XXIX do Prefácio). Mesmo essa suspensão somente tinha sido motivada pelas circunstâncias do momento. Pode-se entrever, está dito em uma carta escrita em nome de Monsieur, de 14 de abril de 1793, que Monsieur gostaria mais ainda que essa obra permanecesse secreta até tempos mais favoráveis (ibid.). Esse livro pode, pois, para todos os efeitos, ser visto como o sistema atual do monarquismo em Verona. Ora, ele respira o mais violento ódio contra toda Inovação, e anuncia o objetivo mais absoluto de restabelecer integralmente o antigo regime, que os Autores chamam a antiga e indefectível Constituição (página 175). Anula-se tudo o que fez a Assembléia Constituinte, à qual se disputa até o direito de reformar os abusos, visto que concedendo-se-lhe esse direito legitimar-se-ia seu poder (página XIX). Diz-se e aqui é repetido que legalmente o Rei conservou o grau de autoridade o qual sempre gozou,
} 
os emigrados fariam uma guerra de morte a todo outro Rei que não ele. Os próprios realistas moderados não estariam de acordo sobre o homem que seria necessário coroar. O novo Rei estaria, pois, na visão da grande maioria dos espectadores da Realeza, na mesma situação que o Diretório. Ver-se-ia chamado a combater igual-

que a Nobreza não perdeu nenhuma de suas prerrogativas, e que o Clero está sempre em possessão de seus bens (ibid.). A Religião Católica, Apostólica e Romana, é declarada a Religião do Estado (página 13 da obra). A prerrogativa real é definida como a reunião do poder legislativo, judiciário e executivo (página 28), o Rei sendo o único Soberano Senhor, o Legislador único, nele residindo exclusivamente a plenitude da autoridade Suprema. O axioma famoso quem quer o Rei, quer a lei, aí é lembrado e defendido (página 20). Nessa obra estabelece-se que o próprio Rei não pode mudar em nada a antiga Constituição (página 31). Desculpa-se Luís XVI por ter aceito a constituição de 1791, mas considerando essa aceitação como sem valor (página 32), o que anuncia o ponto de vista sob o qual se considerará os engajamentos que o pretendente poderia contratar. Protesta-se contra a alienação dos Domínios (página 42), a expropriação dos monges (página 47), a destruição dos direitos da Nobreza (página 50), e busca-se o apoio de Santo Agostinho, d'Hincmar, de Pasquier, de Cujas, e de todas as leis feudais e da Idade Média. Os mandatos imperativos (página 55), o Voto por ordem (página 56), a Doutrina que os Estados Gerais apenas têm a função de levar aos pés do trono suas suplicações (página 37), os privilégios particulares das províncias (página 75), em uma palavra, tudo o que a Revolução destruiu aí é formalmente consagrado.

Depois de ter assim exposto os princípios particulares da Monarquia, os autores passam em suas notas aos princípios gerais. Reprovam a tolerância, como precipitando o homem no abismo do Ateísmo (página 91). Chamam as Revoluções de as Insurreições do mais vil populacho (página 103). Proclamam o direito divino dos Reis, segundo Bossuet. A obediência, dizem eles, a fidelidade, a resignação são deveres que o Moderador supremo dos Impérios prescreveu aos Povos mesmo para com Príncipes que lhes dá algumas vezes em sua cólera (página 108).

Poupamos nossos leitores de um extrato mais extenso dessa obra, assim como das invectivas que contém contra todos os indivíduos. As proscrições nela são anunciadas com furor, generalizadas com cuidado, e detalhadas com prazer. Uma frase sobretudo é bem notável. Depois de uma aproximação da Revolução com as perturbações da França em 1356, os autores acrescentam: Viu-se na necessidade de abater, como animais ferozes, os bandidos dos quais os sediciosos se serviam como outros instrumentos de seus furores (página 148). Ora, os sediciosos de hoje são os fundadores da República. Os bandidos, simples instrumentos, são seus defensores. Deixo a seguir a comparação.

As produções infelizes tem direitos, sem dúvida, a ser julgadas com indulgência, mas somente quando não são, por sua vez, destinadas, por seus autores, a fazer um gênero de mal muito grande, e próprias, por sua natureza, a causar o gênero de mal contrário. A sanguinária exageração dos escritores realistas forneceu armas à exageração oposta. Acabam com a popularidade das palavras Governo, ordem, autoridade, unindo-as sempre a doutrina da Realeza, e às ameaças de vingança. Empurram em direção da anarquia, apresentando sem cessar a imagem do Despotismo, e é sob essa relação, bem mais que sob aquela de seu impotente ódio, que chamam a si, não como indivíduos, pois eles dão pena, mas como agindo sobre a opinião, a desaprovação de todos quantos pensam, e de todos quantos sentem. 
mente seja os inimigos estrangeiros seja os espectadores absurdos do Despotismo e da Teocracia, e seja os amigos da República seja seus adversários pessoais. É preciso confessar que o dilacerar de cinco facções encarniçadas não é para a França um fim que valha uma nova Revolução.

A Realeza absoluta, isto parece estranho dizer, não teria talvez de início tantos inimigos. Como atrairia a si imediatamente um dos dois partidos extremos, o partido mediano poderia a ela se unir, ou melhor dizendo, a ela se submeter. Uma multidão de homens, fatigados das convulsões, resignar-se-ia ao jugo na esperança enganosa do repouso. Mas os inimigos que a Realeza teria de menos, ela não tardaria a criá-los.

Não se sabe o suficiente, na França, sobre o afinco com o qual os realistas puros, mesmo no seu infortúnio atual, entregam-se a todas as suspeitas, separam todos os detalhes e rejeitam tudo o que pudesse desviar por um instante do que eles chamam os princípios fundamentais da Monarquia. Os partidários do antigo regime protestam antecipadamente contra toda espécie de acomodamento, de indulgência, de mitigação. Há, entre eles, vinte frações diferentes que o olho profano, que não é iniciado nos mistérios da Realeza, acha impossível distinguir; e faz parte do caráter particular dessa espécie de homens, que, enquanto todos os partidos buscam se fortalecer e crescer, eles somente pensam em se enfraquecer e em se purificar, e vêem como uma conquista a descoberta de cada detalhe que possa motivar uma proscrição.

Eles trariam esse espírito à França. Juntariam com cuidado todas as páginas da Revolução para estabelecer a data de todos os seus agravos. Para eles não há prescrição. Seu ódio se exasperou envelhecendo, e sua necessidade de vingança tornouse mais imperiosa, na proporção em que foi por mais tempo comprimida.

Remontariam dos agentes do Diretório aos Convencionais, dos Convencionais aos Jacobinos, destes à Gironda, da Gironda aos Feuillants, dos Feuillants aos Legislativos, dos Legislativos aos Constituintes, dos Constituintes aos Monarquistas, dos Monarquistas a todos os culpados do 14 de julho de $1789^{\mathrm{B}}$. Tendo, assim, lançado

\footnotetext{
${ }^{\mathrm{B}}$ Encontra-se em Le Rétablissement de la Monachie a classificação daqueles que a contra-revolução deverá punir: 1. Aqueles que por meio de uma abominável combinação pediram os Estados Gerais.
} 
suas primeiras bases, tornariam a descer por todas as ramificações desses diversos sistemas, que se sucederam e destruíram nos últimos seis anos, e como sua vingança seria ao mesmo tempo política e particular, as vítimas não estariam protegidas por seu número. Em cada aldeia, alguns munícipes, alguns padres juramentados, alguns antigos membros de sociedades populares, alguns compradores de bens nacionais, alguns voluntários, menos justificados por sua resistência à requisição, encontrariam um perseguidor, cujo ódio, engenhoso em distinções, privá-los-ia cedo ou tarde do tímido benefício de uma enganosa anistia.

Não haveria então constituição que abrisse as prisões ao fim de três dias. Haveria uma monarquia que precipitaria para sempre suas vítimas nas prisões. Os atos em pequeno número, que se censura aos primeiros momentos de uma República que tem a necessidade de se estabelecer, seriam bem apagados por uma multidão de atos arbitrários, que cometeria uma Realeza, que teria sede de vingança.

Leiais a história de todas as anistias, e vereis, que não fazem mais do que assegurar os castigos que retardam. Vejais os juizes de Carlos I, levados ao cadafalso, vejais a anistia de 1787 na Holanda, composta de 13 exceções, todas tão vagas, que, sem a inquietude da intolerância, uma só teria bastado; vejais José II protestando antecipadamente contra a indulgência que concederia aos belgas; e acreditais, depois disso, se o podeis, nos comprometimentos da fraqueza, que quer tornar-se todo-poderosa. É tão profunda, que pareceria agradável essa expressão de um homem de espírito, que, pedindo a um governo a liberdade de um de seus amigos dizia: perdoe-se-lhe, apesar da anistia. Para os indivíduos como para os povos, para os soldados como para os

2. Os homens ociosamente obscuros. 3. Os amigos das novidades. 4. Os descontentes. 5. Os ingratos. 6. Os Filósofos ou Ateus. 7. Os protestantes. 8. Os Especuladores abstratos. 9. Os partidários das duas Câmaras. 10. O partido dos Orléans. 11. O partido de Mr. Necker. 12. Os Republicanos. 13. Todos aqueles sem exceção que prestaram o juramento do Jogo da Pela. 14. Os Monarcomanos. 15. Os Monarquistas. 16. Os Feuillants. 17. Os Ministeriais. 18. Os Administradores. 19. Os Membros das Sociedades e dos Clubes. 20. Os restos da primeira Legislatura. 21. Os sucessores que ela escolheu. Depois dessa enumeração cuja forma mesma pertence ao autor, que não fez mais que numerá-la diversamente ao espalhá-la por sua obra, eu determinei, diz ele, a parte que compete ao crime pequeno, e tratei-o com parcimônia. 
generais, para os mais obscuros revolucionários como para os chefes, a única anistia é a vitória.

Como são cegos, os que, rejeitando a glória de sua vida passada, abjurando dos princípios, únicos apologistas de suas condutas, acreditam desarmar implacáveis inimigos apresentando-lhes mãos suplicantes, e uma cabeça despojada de louros. Acolhe-se-lhes, encoraja-se-lhes; não sentem eles, pois, que o complemento da vitória do partido ao qual servem, deve ser seu castigo, que devem cair, e que cairão, ignóbeis vitimas. O exemplo de sua apostasia, e de seu suplício, depois de sua desonra, provando que para seu primeiro crime não existe expiação, é bem mais instrutivo no sentido da tirania, do que a punição de crimes verdadeiros, que somente atormentam os criminosos. A morte de um homem do 2 de setembro só espanta a anarquia, a de um constitucional espanta a liberdade.

É sobretudo a essa classe que me dirijo; sei que, entre esses homens, que deram os primeiros passos em direção a reabilitação da espécie humana, existem vários que seguiram a liberdade sob todas as suas formas, que sofreram sobre sua pátria, não podendo mais servi-la, e que, ligados outrora a uma monarquia culpável, fazem hoje, em se modesto retiro, votos pela República, porque só nela está a liberdade. Mas, se existem outros, que, afastando de si todas as lembranças, não viram mediação, em sua intrigante atividade, entre o poder e a perfídia, e, cessando de ser chefes de um partido, fizeram-se agentes de um partido contrário, que aprendam que é sua perda que desejam e que o abismo que cavam deve engoli-los.

Quando as seções de Paris atacavam a Convenção, os Realistas fora da França faziam votos contra as seções de medo que sua vitória trouxesse o que eles chamavam um sistema moderado. Após três anos sua maior inquietude, é que os Constitucionais triunfem; seus infatigáveis escritores produzem a cada dia volumes, não em favor de sua causa, não contra os crimes bastante numerosos que mancharam a revolução, mas contra unicamente os Constitucionais e seu prazer é colocar Bailly com Marat, e Lafayette com Robespierre.

Essas disposições seriam redobradas pelo único partido do interior ao qual os Realistas, na sua pureza consentiriam em se unir. A Vendéia misturaria à sua into- 
lerância seu fanatismo, e reforçaria a perseguição política com a perseguição religiosa. Veríamos renascer o Cristianismo da Idade Média, depois que o crescimento de suas forças o tivesse livrado das deferências e antes que a filosofia tivesse modificado sua influência.

Seria então que os homens mais amigos do repouso seriam obrigados a se unir para sublevar o jugo que pesaria sobre suas cabeças; procurariam então pelos restos do partido Republicano que teriam deixado tão loucamente esmagar, e recomeçariam uma desigual e sangrenta luta, para chegar enfim a essa liberdade tão freqüentemente ultrapassada em todos os sentidos, e que hoje somente a eles resta assegurar.

Ela triunfaria, não se pode duvidar. À sua voz, acorreriam todos os que pensam, na Europa, todos os que um novo despotismo teria sublevado, todos os que veriam avançar a noite espessa e desastrosa do século XIV, os que, enfim, ávidos de liberdade vieram procurar na França alguns perigos, talvez, mas uma causa para defender. Vendéias republicanas se formariam, menos atrozes, mas não menos temíveis que a Vendéia católica. A verdade seria sua religião, a história sua legenda, os grandes homens da Antigüidade seus santos, a liberdade sua outra vida. Eles não esperariam ressuscitar em três dias, mas combateriam e morreriam livres ${ }^{\mathrm{C}}$.

Fui muito longe talvez nesse quadro do que não pode acontecer. Quando se impõe, por um instante, de supor a queda da liberdade, o pensamento se volta, sem querer, em direção aos esforços, que se fariam por ela, e o sentimento de seus perigos, mesmo imagináveis, tem necessidade de ser suavizado pelo sentimento de que partilhando-se sua sorte, retardar-se-ia talvez sua queda e a ela não se sobreviveria.

A guerra civil, eis o que trará à França toda espécie de Realeza. Acrescentarei uma observação, que até o presente me parece ter escapado a todos os partidos, qual seja, que os elementos da discórdia não existem somente entre os republicanos e os realistas puros, eles não tardariam a explodir entre os próprios realistas puros. Ter-

\footnotetext{
${ }^{\mathrm{C}}$ Sabe-se que os Vendeanos fanatizados enfrentavam a morte persuadidos que, onde estivessem, ressuscitariam três dias após seu suplício.
} 
se-á dificuldade em acreditar talvez que os princípios democráticos tenham lançado profundas raízes na alma dos emigrados. O exílio, os perigos, o fanatismo, estabeleceram entre eles um tipo de igualdade, que não deixariam perder-se. Esses ardorosos inimigos dos direitos do homem reclamam sem cessar para sua classe, esses direitos que querem retirar de nossa espécie. A seita feudal tem seus niveladores. $\mathrm{O}$ amor da independência fez progressos espantosos nos batalhões da monarquia. Jamais houve exército mais indisciplinado que aquele que se diz reunido em nome da obediência. Os campeões da aristocracia pretendem que não deve haver nenhum privilégio entre os aristocratas, e viu-se-lhes opor com furor a que o nome do primeiro dos pares de França precedesse nomes mais obscuros, num protesto em favor da distinção das posições.

Esse sentimento, hoje comprimido pelo interesse de sua causa, pela pressão da adversidade, e pela obscuridade de sua existência, desenvolver-se-ia depois do triunfo e o sangue francês, que correu tão gloriosamente para estabelecer a igualdade de vinte e cinco milhões de homens livres, correria talvez com opróbrio para estabelecer a igualdade de duzentos mil opressores. 


\section{CAPÍTULO IV}

\section{Dos Ressentimentos e dos Males Irreparáveis}

Existem alguns homens, sem dúvida, dos quais não se pode exigir que se liguem à República: são aqueles, que, na Revolução, perderam o que tinham de mais precioso. Não vivem mais no presente, são estrangeiros ao mundo, habitam os túmulos. Tudo o que ainda pode existir não é nada para eles diante do que não existe mais. Mas hoje que os autores de seus males foram punidos, ordena-se-lhes não mais reclamar por vingança. A pátria não perde jamais o direito de ser ao menos respeitada, no momento em que não é servida. O isolamento, o ensimesmar-se, a espera da morte, eis o que resta aos desafortunados, que um sofrimento irreparável curvou sob seu império.

Há certas naturezas, não diria mais fortes (pois o que há de mais enérgico que a intensidade da dor), mas mais imperiosamente dominadas pela paixão de serem livres, e que os arrependimentos não põem a perder os princípios. Tais são os amigos de tantos Republicanos, imolados em todas as partes da França, sob o reino da Tirania. Eles teriam também lágrimas para extravasar. Viram cair seus companheiros de armas, de trabalhos e de esperanças, seus guias, seus êmulos, e seus irmãos. Mas reúnem seus olhares sobre o fim comum, que os unia àqueles que não existem mais, sobre a felicidade de sua pátria e sua liberdade.

Que eles são diferentes desses homens, a um só tempo amargos e frívolos, insensíveis, mas vingativos, consolados sem estar serenados, que esqueceram suas afeições, sem perdoar a sua pátria, que, divertidos, ou compensados, quando correm atrás do prazer, retomam o lamento, quando se trata de motivar o ódio, culpados hipócritas, profanando o que há de mais santo sobre a terra, as lágrimas e a dor, e fazendo do crime uma virtude para comete-lo impunemente. Esses não podem pretender a nenhuma deferência merecida pelo sofrimento. Quem quer que sorriu ao perder o que amava, renunciou ao direito de se vingar, e a possibilidade da distração obriga-os à indulgência. 


\section{CAPÍTULO V}

\section{Do Restabelecimento do Terror}

Somente um motivo poderia ainda impedir os homens honestos de dar apoio ao Governo, é a idéia bastante difundida de que o terror está prestes a se restabelecer. Aqueles que nutrem esse medo, fundam-no sobre o que tomam por medidas revolucionárias, e sobre o que chamam de nomeações jacobinas. As eleições, dizem eles, são retirados do povo. O Diretório acumulou os poderes; homens de sangue são nomeados aos postos: eles saem das prisões, com seus furores antigos, fortificados por ressentimentos novos.

Assim falam os homens que acreditam se vingar do governo décemviral, prodigalizando a desconfiança ao governo constitucional.

Felizmente cada dia responde à essas inculpações exageradas. A cada dia, o governo tornado mais forte, mostra-se mais suave; retira das mãos justamente suspeitas, um poder perigoso e, assegurado sobre sua fraqueza, afasta agentes cuja exageração, durante alguns instantes, propiciou-lhe segurança.

O que vou dizer, não se destina pois a justificar o que logo não existirá mais, mas a impedir que a lembrança do passado envenene o futuro. Apresso-me em declarar antecipadamente que os princípios que enunciarei somente se aplicam à crise inseparável dos primeiros momentos de uma constituição; essa crise felizmente está perto de seu término, e prolongar a aplicação desses princípios, seria pervertê-los e deles fazer abuso.

Reportemo-nos de início à época na qual o Diretório foi constituído. Por uma sequiência inevitável a todo governo provisório, após vários meses, os depositários passageiros de uma autoridade que devia cessar viviam o dia a dia legando todos os embaraços do porvir à Constituição futura. $\mathrm{O}$ tesouro nacional estava exaurido, a riqueza pública incerta, as fortunas particulares destruídas, os exércitos desorganizados, dois dentre eles obrigados a recuar, os inimigos da Convenção irritados com suas derrotas mais do que abatidos. Assassinatos, tratados por muito tempo com uma ligeireza culpada, assassinatos de homens talvez criminosos, mas que não eram por isso menos crimes, anunciavam o estabelecimento de um terror em sentido 
inverso. Infeliz do país onde os crimes são punidos pelos crimes, e onde se massacra em nome da natureza e da justiça!

Era preciso dar um basta imediato a esse deperecimento político. Era preciso que o Diretório, mostrando-se forte desde seu nascimento, rejeitasse a funesta herança da desacreditada Convenção. Se o Diretório deixasse por um instante que se duvidasse dele, tudo estaria perdido.

Entretanto, a luta de Vendemiário havia desencaminhado vários homens estimáveis. Outros tomados por essa apatia, doença da honestidade, não gostavam de se ver colocados entre dois partidos. Uma terceira e numerosa classe tinha se retirado, escrava do que se chamava então a opinião pública.

Não se faz uma idéia justa da influência e da natureza dessa opinião que a si mesma não se conhece. É preciso, para apreciá-la, tê-la visto nas seções de Paris, à barra da Convenção, no seio das assembléias primárias, ao mesmo tempo reclamando e violando todas as formas, sem cessar injusta na sua impaciência, mas sempre de boa fé em seus intentos, nunca confessando sua tirania e ardorosa inconseqüência, abusando das instituições que ela reprovava, e esmagando com os pés as leis que havia exigido. Potência arbitrária e misteriosa, tem sempre um fim louvável e sempre o ultrapassa. Inimiga implacável dos meios legais que a incomodam e da razão que quer moderá-la, é o instrumento dócil de quem a lisonjeia, mesmo que para conduzi-la no sentido mais oposto às suas intenções. Crê justo tudo o que ordena, como se fosse a vontade geral, e o executa pela violência, como se não fosse mais que a vontade de uma facção; queixa-se como se a oprimissem, e ameaça como se fosse todo-poderosa; desdenha as deferências, abjura seus amigos, quando, servindo-a, esforçam-se para contê-la; quer que seus chefes a precedam em lugar de dirigi-la; parece calculada enfim para se impor a essa maioria, mais estranha ainda, que se procura em lugar de se declarar, cuja ambição é apenas ser precedida, e que prefere adotar com a segunda ordem medidas violentas, a se colocar na primeira para fazer triunfar, sem perigo, os moderados.

O Governo não podia empregar homens dominados por essa opinião. Era preciso reconduzir a uns, convencer a outros, reanimar a terceiros; estavam eles por si mesmos alienados, flutuantes, abatidos? 
As circunstâncias exigiam espíritos ardentes, capazes de medidas rápidas, que seria necessário conter, mas que não fosse necessário incitar, com os quais o Diretório pudesse se assentar pelas intenções que não se dão, e das quais só tinha a temer o exagero que se reprime.

Entre aqueles que reuniam essas condições, vários tinham merecido graves censuras; todos eram acusados por algum partido.

A Deus não agrada que eu queira desculpar aqueles contra os quais depõem fatos execráveis, há homens que merecem para sempre o horror. Se alguma coisa podia desonrar o sentimento que se experimenta defendendo a liberdade, seria pensar que esses homens também se dizem seus defensores; se não estão em suas fileiras, apoderaram-se de um estandarte que, por mais desonrado que esteja, ainda pode assemelhar-se ao seu, e para completar o entusiasmo, é preciso tê-los por inimigos.

Mas evitemos confundir com esses seres, marcados por um eterno anátema, aqueles que só estão expostos a rumores vagos e ao burburinho do ódio. Desde o 14 de julho, quem não foi denunciado? Quando se vê Bailly e Pache, La Rochefoucaud e Marat, Condorcet e Saint-Just, Sieyès e Robespierre, expostos às mesmas injúrias, pode-se acreditar ainda nas reputações revolucionárias? As facções só têm um estilo, não aplicam as invectivas aos nomes, juntam, ao azar, os nomes às invectivas, poderiam passar de mão em mão as acusações que prodigalizam, e uma única filípica serviria a todos os partidos.

As escolhas do Diretório deviam ser condenadas, quaisquer que fossem. Sem dúvida, essa condenação só foi bem merecida à alguns de seus agentes, e fica-se feliz ao pensar que ele vem, enfim, de se pronunciar contra eles com uma severidade que o honra. Mas sem falar dessas escolhas, que ele já reparou, outras escolhas, reprovadas com menos justiça, mas todavia com algum fundamento, não tiveram sua utilidade?

Um dos mais funestos erros das facções, é não querer jamais acreditar no arrependimento. Elas tomam por uma maneira de ser, uma ação isolada, uma febre alta por estado habitual; transferem a toda uma vida, o erro de um ano; eternizam o que não seria mais que passageiro. Seres versáteis que somos, ao mesmo tempo 
que refletimos sobre nós mesmos, sentimo-nos vacilar a cada passo, por qual absurdo julgamos tão diferentemente os nossos semelhantes? Tiremos proveito pelo menos de nossa instabilidade, de nossa inconseqüência, todos os defeitos de nossa fraca natureza, para não darmo-nos uma seqüência, uma profundidade criminosa, incompatível com esses defeitos.

Há ações que são irreparáveis, que levantam entre um criminoso e nós, entre um criminoso e ele mesmo, uma barreira eterna; mas essas ações não são comuns, e nunca se pode pronunciar uma condenação sem apelação contra uma classe ou contra toda uma seita.

Era, pois, fácil prever o que o espírito de partido se obstinava em negar, que circunstâncias essencialmente diferentes, uma constituição no lugar de um governo revolucionário, uma rota traçada no lugar de um campo de batalha, um estado estável no lugar de um assalto, chamariam aos justos limites os que, entre os homens ardentes, só estavam desencaminhados.

Ora, no momento em que os agentes do Governo devem estar investidos de grandes poderes, e em que os limites desses poderes, apesar de traçados pela constituição, não estão ainda consagrados pelo hábito, é vantajoso, diria mesmo que é necessário, para o estabelecimento da liberdade, que esses agentes estejam em oposição com a opinião. Estão por isso submetidos à vigilância do ódio; se estivessem no sentido da opinião, eles não poderiam impedir-se de ir muito longe.

Disso temos um terrível exemplo com o que se passou desde Robespierre. A confiança universal tinha colocado homens honestos nas funções administrativas. Eles deixaram organizar-se companhias de assassinos. É que estando a opinião dirigida contra aqueles que se assassinava, os Magistrados que deviam sua nomeação a essa opinião, não ousavam resistir-lhe, para defender esses homens, e colocando-a no lugar da lei, acreditavam preencher um dever moral, faltando a seu dever judiciário.

Quando, ao contrário, os agentes do governo estão em sentido inverso ao da opinião, ela traça-lhes estreitos limites. Buscam contra ela um suporte na execução mais estrita da lei. Se tivessem a opinião a seu lado, a lei seria logo impotente. É 
um dique que lhes é útil, quando nele se apoiam para resistir à torrente, mas que não resistiria se eles se unissem à torrente para derrubá-lo.

Uma segunda vantagem, é que o governo, que os nomeou, sente-se responsável por sua conduta. É certo que eles não permanecerão aquém dos limites, mas o perigo é que eles o ultrapassem, pondo-se todo o governo em repressão. O governo não se entrega a eles, dirige-os: não os incita, retêm-nos.

Dessa combinação de disposições diversas, da confiança do Governo nas intenções, de sua desconfiança nos atos, do desfavor da opinião, e do sentimento profundo dos agentes, de que a lei rigorosamente executada é sua única salvaguarda, resultam, ao mesmo tempo, a exatidão e a decisão, a moderação e a energia.

Os fatos bem o provaram. Excetuando-se alguns homens, já despojados do poder, os agentes mais desacreditados enganaram a espera do ódio e do medo combinados. Cometeu-se a seu respeito o mesmo inconcebível erro que, em todo o curso da revolução, caracterizou seus inimigos. Exasperou-se-lhes pelos erros cometidos, exagerando-se seu poder. Como que incitando-os a cometer crimes, lamenta-se antecipadamente a impunidade da qual gozarão. Desafiou-se-lhes, mas anunciando a impossibilidade de resistência. Mostrou-se-lhes o desprezo, mas garantindo-lhes a submissão. Que se compare, entretanto, seus atos mais violentos, com todas as épocas da Revolução, que se considere que esses atos vão ser anulados, e abençoar-se-á a constituição. Sentir-se-á que, se, em semelhantes circunstâncias, ela pôde oferecer aos oprimidos a segurança, proteção, reparação das injustiças, em tempos mais calmos, ela dará felicidade, repouso, liberdade. Desgraçado aquele que quereria se aproveitar de suas próprias formas para derrubá-la, e que somente invocaria a lei para voltar à tirania.

Meditais que foi cinco meses depois do 13 de Vendemiário, que a liberdade de imprensa está consagrada, talvez em uma grande amplitude, mas por uma discussão respeitosa e imparcial, e acusais a França, se ousais a seguir, de estar em revolução, ou sob um despotismo qualquer.

O governo exerce ainda, é verdade, sobre a bolsa e sobre os espetáculos, uma espécie de autoridade inquieta e talvez pueril; mas a experiência e a dignidade proporcionados pelo poder darão em pouco tempo, sem dúvida, um fim a esses erros 
minuciosos. Perderá esses temores que, engrandecendo seus objetos, tornam terrível o que não seria mais que desprezível. Aprenderá que a grande arte é governar com força, mas governar pouco, ter uma mão de ferro, mas empregá-la raramente, servirse de sua espada contra inimigos temíveis, mas não ameaçar com ela aqueles cuja pequenez torna seus esforços a um só tempo ridículos e infrutuosos. Se uma facção insensata cessa de entravar a marcha do Diretório, este não será mais forçado a lhe opor adversários ardentes como ela. Todos os homens honestos, que apoiarem sinceramente a República, serão chamados à servi-la. Eles assegurarão a calma e a dignidade de uma instituição que esforços inúteis poderiam agitar ainda, mas não poderiam destruir.

Nada trará de volta o terror; mas que se dê graças por isso às circunstâncias, e não à esses vãos declamadores, que só fazem predizer seu retorno. São eles que o provocam. Injuriam, ultrajam ${ }^{\mathrm{D}}$, querem amedrontar ou irritar os homens do governo, que, felizmente, conservam seus interesses e seus deveres. Esforçam-se para colocar o governo entre medidas violentas e sua desconsideração. Voltam contra ele até seus atos de justiça. Anistia o governo um antigo amigo da liberdade? Seus jornais mentirosos apressam-se em publicar que ele hesita em voltar à sua pátria, e que desconfia de suas novas instituições. Sacrificam à seu ódio até mesmo seu partido. Recentemente um infeliz foi pego, fugindo de uma sentença rigorosa. Esses homens, como para lhe retirar toda possibilidade de ser absolvido, apressaram-se em publicar que sua absolvição provaria a legitimidade da insurreição de Vendemiário, ligando assim à sua morte a honra e a legalidade do governo, que, felizmente, soube desprezar

\footnotetext{
${ }^{\text {D }}$ Li com pena em alguns jornais de resto estimáveis, e que não se deve confundir com aqueles de que trato aqui, amargas e violentas invectivas contra o governo. Observaria a seus autores, que não teriam empregado esse estilo sob o antigo regime, de onde concluo, primeiramente, que cometem o erro de pintar o regime atual, como não sendo mais livre e menos vexatório que aquele da Monarquia; e em segundo lugar, que cometem o erro ainda da acreditar que se deve menos deferência à um governo republicano, do que à um Rei. Não é como Rei, mas como governo, que um Rei pode exigir consideração; e o Diretório, encarregado de administrar para uma grande nação, tem o direito a tudo o que havia de razoável no respeito antigo pela Realeza. Somente a superstição dele deve ser subtraída, e a decência não é a superstição.
} 
suas provocações. Para eles, joguetes enfurecidos de uma raiva cega, o repouso de sua pátria não conta nada, nem a vida de seus amigos, e se o Diretório fosse fraco o forçariam a ser cruel.

O espanto cessa, e a indignação redobra, quando se sabe que entre esses homens há agentes de Robespierre, que um dos mais marcantes dentre eles foi o panegirista de Collot d'Herbois. Não se deve deixar de repetir essa terrível verdade: é preciso dizer sem cessar aos franceses, que os instrumentos ferozes da antiga tirania provocam hoje, sob formas realistas, o mesmo terror do qual foram os suportes. 


\section{CAPÍTULO VI}

\section{Das objeções extraídas da experiência, contra a possibilidade de uma República em um Grande Estado}

Contudo, seria bem inútil trabalhar para apaziguar, para unir, para convencer, se, como nos repetem tantos ecos infatigáveis, a República fosse impossível.

Tudo o que não aconteceu parece assim. A História não oferece nenhum exemplo de uma República de 25 milhões de homens; imediatamente disso conclui-se que uma República de 25 milhões de homens é uma quimera.

Parece-me que é estranhamente abusar da experiência. Ela só pode nos esclarecer sobre o que nos mostra. O que não existiu não é de sua alçada. É preciso sempre que ela se apoie sobre um fato, ou sobre uma tentativa, o que é um fato. Querer estendê-la sobre o desconhecido, é mudá-la de suas bases.

Quando se pensa que as revoluções físicas da terra, as calamidades políticas das nações, as transformações das sociedades, colocaram entre nós e tudo o que ultrapassa quatro mil anos, uma barreira insuperável, espantamo-nos com a presunção dos homens, que se autorizam do que não viram, para decidir do que é impossível, e que acreditam colorir sua arrogância colocando-a toda em negações.

Eles parecem sobretudo absurdos, quando se pensa que o argumento que empregam foi empregado há cem anos, há duzentos anos, há mil anos, e que assim teorias anteriores arguíram sucessivamente da impossibilidade de todas as descobertas do espírito e de todas as combinações do acaso.

Antes da formação das grandes sociedades, afirmava-se, sem dúvida, que uma sociedade numerosa não podia subsistir, e apoiava-se na experiência. O vulgar de cada século cita com ênfase o passado contra o futuro; aquele que the sucede o vê desmentido pelo acontecimento; mas insultando a seu erro, ele o imita, e substituindo somente as negações, persegue não menos, infatigavelmente, suas proscrições proféticas.

Se a Realeza, tal como a vimos na França, não tivesse jamais existido, sua impossibilidade pareceria evidente. Quando se reflete sobre a idéia de confiar à vontade de um só o destino de todos, sente-se que só lhe falta ser nova para parecer absurda. 
Se essa Realeza só tivesse existido em pequenos Estados, far-se-iam, contra a possibilidade de constituir vinte e cinco milhões de homens numa monarquia, cem raciocínios especiosos.

Em um pequeno Estado, dir-se-ia, é menos perigoso revestir um só homem do poder supremo, porque esse homem está, por assim dizer, sob os olhos de todos. A piedade física age sobre ele, pela presença de sua vítima. Ele não pode se fazer nenhuma ilusão. Se é cruel, é por crueldade; se é opressor, é por tirania. Em um vasto império, seria opressor ou cruel por fraqueza; crer-se-ia benfeitor ou justo, a partir do testemunho interessado de uma classe circundante, e dar-se-ia assim a si próprio provas das virtudes que não teria.

Em um pequeno Estado, as funções do Príncipe enquadradas nos limites de suas possessões estreitas, não o obrigam a delegar seus poderes; em um grande país, sua autoridade corromper-se-ia ao se afastar de sua fonte. Pode-se dizer da injustiça do que diz Virgílio da reputação: Vires acquirit eundo.

A vantagem da Realeza é que tudo seja supervisionado por um só homem e se reporta a um só plano; essa vantagem desapareceria em uma grande monarquia. Ela reuniria os inconvenientes de uma República, pela multiplicidade dos agentes, aos flagelos do despotismo por sua arbitrariedade.

Em um pequeno Estado, o Príncipe não pode assoldadar exércitos numerosos; suas forças militares não podem tornar-se instrumentos de opressão; pois não é o número proporcional dos soldados, mas seu número positivo que é perigoso. Cem homens não subjugam dez mil; cem mil homens impõem-se a milhões. O chefe de uma monarquia extensa, obrigado a manter de pé um tal exército, seria ao mesmo tempo tirano por meio dele e seu escravo. Ele próprio não poderia resistir ao poder dessa massa. Uma vasta monarquia favoreceria infalivelmente o despotismo guerreiro.

Enfim, a opinião de seus vizinhos contém o soberano de um pequeno país: o que quer faça, deles está cercado; a eles não pode escapar, nem desafiar, nem esquecer; esse freio tornar-se-ia nulo para o monarca de um vasto império; a opinião iria se quebrar contra suas fronteiras, e jamais chegaria até ele. 
Temeria fatigar o leitor, detalhando mais longamente tudo o que se poderia alegar em favor de uma idéia falsa; já disse o bastante para provar que essa maneira de raciocinar só conduz ao terror. Não se poder argüir de impossibilidade absoluta a nenhuma forma de governo. Não nos assemelhemos a esses povos ridículos, que, em suas cartas geográficas, colocam além dos países que conhecem, e eles só conhecem o seu, terras inabitadas, fábulas e desertos.

Com os governos ocorre o mesmo que com o corpo humano. Para quem o considera abstratamente, parece não poder resistir um único dia aos choques aos quais está exposto. Um célebre anatomista não ousava fazer quase nenhum movimento; não havia nenhum, dizia ele, que, vista a fragilidade de nossa estrutura, não punha nossa vida em perigo.

Os governos subsistem, a despeito das teorias, porque em todas as nações a massa quer essencialmente e quase exclusivamente o repouso: submete-se a tudo o que é tolerável, e, por sua flexibilidade, torna tolerável o que antes não o era. 


\section{CAPÍTULO VII}

\section{Das vantages do Governo Republicano}

A despeito das Teorias, todos os governos são possíveis na prática. No entanto, se quiséssemos concluir disso que todos são indiferentes, cairíamos em um erro grosseiro. Meu objetivo foi provar que, todas as coisas iguais, a República, na França, unicamente porque está estabelecida, deveria ser preferida. Se tivesse desejado demonstrar sua preeminência abstrata, teria alegado mil razões que nem cheguei a indicar.

Teria lançado meu olhar sobre a história; as Monarquias nela se distinguem das Repúblicas, por seu colorido uniforme e baço. Elas condenam uma grande parte de nossas faculdades e de nossas esperanças à inatividade. Ora, o repouso é um bem, mas a inatividade é um mal; os homens não querem ser perturbados, mas não querem de nenhum modo ser paralisados; e se a Monarquia, por sua natureza, coloca inúteis entraves à atividade, é já, digam o que quiserem os que especulam sobre o sono da espécie humana, um vício imenso na Monarquia.

Observaria que essa inatividade é a fonte de um de nossos maiores males, de um mal que não é somente político, mas individual, desse sentimento árido e devorador, que consome nossa existência, que descolora todos os objetos, e que, semelhante aos ventos quentes da África, mirra e murcha tudo o que encontra. Esse sentimento, que, nem as línguas antigas, nem aquela do único povo que foi livre, na Europa moderna, antes dos franceses, podem designar, nasce principalmente dessa privação de objetivo, de interesses, e de esperanças, ainda que estreitas e pessoais. Ele persegue não somente o obscuro súdito das Monarquias, mas os Reis sobre seus tronos, e os ministros em seus palácios, porque a alma é sempre fechada quando é empurrada para o egoísmo; há sempre alguma coisa de baço, de aviltante, no que só olha para si, no que não emana da natureza e não marcha para a liberdade. A ambição, nas Monarquias, mesmo quando quer se elevar ao bem, sempre reflui à si mesma. Não se pode esquecer, não se pode entregar ao entusiasmo, não se é eletrizado pelo reconhecimento de seus iguais, curva-se diante dos agradecimentos de 
um senhor. Sentimo-nos diminuídos diante da pequenez que nos cerca. $\mathrm{O}$ vergonhoso tédio marca com seu carimbo tudo o que é ou degradado pela subserviência ou distraído por ignóbeis gozos, ou preservado do contágio pelo estudo e o isolamento; e se a República, que se levanta, enfrenta ainda tantos entraves, e sobretudo encontra tanta inércia, é à educação monárquica que é preciso responsabilizar. Os caracteres são ainda muito pequenos para os espíritos; estão nervosos, como os corpos, pelo hábito da inação ou pelo excesso de prazeres. A liberdade, que se estabelece, por assim dizer, apesar dos homens, sente, quase a cada instante, dobrar em suas mãos os instrumentos dos quais se serve.

Acrescentaria que hoje, mais do que nunca, a inatividade seria um suplício para um povo acostumado há seis anos a se ocupar dos maiores interesses e a exercer todas as suas forças na carreira imensa que acabou de se abrir diante dele. Aqueles que trabalham para a Realeza seriam os primeiros a sofrer com seus sucessos. A agitação do caminho aturdiu-os sobre o fim; mas à exceção do pequeno número, que continuaria a agir oprimindo, os outros se achariam oprimidos pela imobilidade à qual os condenaria sua própria obra.

A monarquia, de resto, mais desloca a ambição do que a extingue; ao retirá-la do caminho traçado pela lei, empurra-a para o do arbítrio, colocando assim somente mais baixeza na agitação, condenando a esperança à personalidade, e degradando, enquanto que a ambição popular eleva ao mesmo tempo em que embriaga.

Procuraria, enfim, se a sublime descoberta do sistema representativo, conservando o fim sublime da ambição republicana, e moderando sua fermentação, não estabelecesse um justo meio, e se mesmo essa vantagem não é em razão da extensão de uma República; porque a grandeza dos objetos faz desaparecer as pequenas paixões, exclui os pequenos meios, e coloca entre os homens, uma distância que não mais permite que se abalroem em suas disputas, seus interesses ou seus ciúmes pessoais.

À objeção repetida da complicação das instâncias, teria respondido que o mesmo número de instâncias é sempre necessário. A pretendida simplicidade da Monarquia é ilusória. Um Rei, como todo poder executivo, é forçado a delegar 
seu poder, e a Realeza somente torna essas delegações inevitavelmente arbitrárias e freqüentemente absurdas.

Aos abusos da liberdade, oporia os abusos do poder. O poder é mais embriagador que a liberdade. Um poder muito estendido é por si só uma coisa abusiva: tudo o que dele decorre ressente-se de sua fonte; enfim, o abuso do poder, prometendo prazeres mais numerosos e menos definidos, oferece muito mais tentações que o abuso da liberdade.

Desenvolveria uma vantagem, bastante pouco notada, da República sobre a Monarquia, que é a conservação das formas livres.

Censura-se freqüentemente às Repúblicas de disfarçar a opressão e prostituir os nomes mais santos à mais abominável tirania; é sem dúvida um grande mal; mas aqueles, que, nesse abuso, só vêem um mal, parecem-me visar apenas um lado da questão.

Conhece-se bastante o poder das palavras sobre os homens. Esse poder é algumas vezes bem funesto, mas ele tem freqüentemente uma grande utilidade.

As palavras têm sobre nós uma tal influência que restauram as idéias. Separadas delas, por uma causa estranha, voltam à elas se juntar no momento em que a causa não mais existe. As formas perpetuam o espírito, e apesar delas poderem ser horrivelmente pervertidas, assemelham-se a essas árvores que são fáceis de dobrar, mas cuja elasticidade fá-las endireitar, quando para-se de comprimi-las.

As formas republicanas conservam um tipo de tradição de liberdade que se liga à verdade, depois das interrupções causadas pela tirania; as formas despóticas, ao contrário, consagram a escravidão, de maneira que o espírito servil sobrevive à servidão, e que a queda de um senhor não encontra no cérebro dos escravos nenhuma fibra que repercuta a independência.

Se os horrores de Robespierre se tivessem exercido em nome de um direito divino, de uma submissão implícita, ou mesmo em nome da ordem e do repouso, pretexto das monarquias, o 9 de Termidor, não reencontrando mais do que as idéias de direito divino, de submissão implícita, teria parado os massacres, mas não teria convocado à liberdade.

Não é por falta de revoluções que os povos da Ásia nunca foram livres; é por falta de ter tido palavras e formas, que, no próprio instante em que o jugo fosse quebrado, pudessem mostrar-lhes um outro fim, que não o de substituí-lo por um jugo novo. 
Aplicaria as mesmas observações à moral. A esse respeito também as formas reconduzem ao fundo. A corrupção se encoraja pelo exemplo e diminui ao se disfarçar. Desgosta-se do vício quando seu resultado não produz mais do que embaraço. Entrase na seriedade de um papel que é necessário desempenhar sempre e corretamente, e por hábito torna-se o que antes se queria parecer por hipocrisia. A República não pode subsistir sem certos gêneros de moralidade; mas como tudo na natureza tende a se conservar, ela reproduz os gêneros de moralidade que são necessários à sua existência.

Observaria a seguir que a teoria da monarquia não é uma idéia isolada mas está ligada intimamente a uma questão muito mais importante, e cujas conseqüências se estendem sobre todas as ramificações da ordem social, quero dizer, a hereditariedade, a desigualdade das posições. Um Rei não pode existir sem nobreza. É preciso pois examinar as vantagens e os inconvenientes da hereditariedade.

Uma de suas primeiras vantagens, é estabelecer, diz-se, um tipo de governo de opinião, de subordinação das relações, que dispensa o governo propriamente dito de empregar seus meios diretos, e que, preparando à submissão a massa do povo, ela somente é capaz de manter.

Parece-me que se exagera muito o império das lembranças sobre a multidão. As lembranças são uma moeda, que só tem curso nas classes interessadas a lhe conservar um valor. Somente essas classes são capazes de sentir o que se chama a consideração. É necessário à alma um alto degrau de refinamento para se abrir a essa espécie de superstição errônea, mas delicada, cuja existência cavalheiresca compõe-se das nuvens do passado. As almas grosseiras à elas estão fechadas, como à todas as sensações modificadas, complicadas, vagas, e melancólicas. Aquelas que lhe são suscetíveis, não têm necessidade desse freio; elas não o seriam menos de um respeito mais razoável.

Quanto ao povo o que ele respeita é o poder. Se parece ligar à idéia da nobreza um sentimento de veneração mais profundo que aquele que testemunha mesmo aos parvenus poderosos, é que acredita mais na duração do poder dos nobres. Não é sobre o passado, mas sobre o futuro que se coloca esse sentimento; não é da memória, mas da previdência. A prova disso é que quando se convence de que a nobreza está para sempre separada do poder, o prestígio logo se dissipa. Basta ver como, nos 
países menos livres, ele trata esses nobres, despojados e sem pátria, quaisquer que sejam os nomes que carreguem nos seus infortúnios. Ora, o hábito de ver o poder ligado a certos cargos, em lugar de vê-lo unido a certos nomes, produziria sobre o povo o efeito da nobreza, isto é, a convicção que o poder está irrevogavelmente lá.

Para que a nobreza tenha influência sobre a classe que é preciso conter, um poder durável lhe é pois necessário, e com um poder durável a nobreza torna-se inútil.

A única vantagem incontestável da hereditariedade é conservar na administração um espírito uniforme, ou que ao menos, por se modificar insensivelmente, opõe-se a toda mudança brusca e previne toda convulsão; mas essa vantagem se reencontra, e mesmo a um bem mais alto degrau, em uma forma de governo que, renovando por parte os depositários da autoridade, faz da própria autoridade um ser abstrato, imortal e imutável.

Depois de ter assim refutado as vantagens aparentes da hereditariedade, ressaltarei seus inconvenientes reais.

Aqueles que representam a hereditariedade como o efeito e o complemento da desigualdade natural, avançam um grosseiro sofisma; é, ao contrário, a destruição dessa desigualdade, é um nivelamento em sentido inverso.

É a desigualdade natural um bem? Respeitai-a em vossas instituições. Deixai entre os homens a distância das faculdades, dos talentos, da indústria. Essa distância não irrita, porque ela parece sempre possível de ser ultrapassada. Um sentimento profundo diz ao homem que a vontade firme, a coragem, a meditação podem levá-lo a todas as posições. Quando sua altivez não o eleva, sua indolência o adormece, e seu amor próprio o consola acariciando essa vaga e lisonjeira possibilidade. Ele não freme, escravo desarmado; entrega-se ao repouso, depois de ter voluntariamente deposto suas armas.

É essa desigualdade um mal? Porque, pois, elevar, ao seu lado, uma nova desigualdade que não a destrói, mas que a ataca? Fazer do acaso um poder inimigo da natureza, não é dobrar o perigo dos choques? Para estabelecer a ordem, imagineis vós duas forças contrárias, das quais uma aniquila por sua massa, a outra perturba por sua violência? Existem tão poucos elementos de discórdia que é necessário criar novos, que, não podendo se aliar a nenhum outro, afasta-os, divide-os, mantendoos em um eterno e convulsivo movimento? 
Os Realistas fazem apelo, contra a República, à história; eu apelaria à história também, contra a hereditariedade.

Essa instituição tem em cada século excitado uma revolta, acendido uma guerra, causado um massacre. A Inglaterra, a Alemanha, a França, a Itália, nos mostram igualmente os camponeses correndo às armas contra os senhores. Por toda parte vemos a espécie humana protestar, em episódios de sangue, contra esse insulto feito a seus direitos. A jacquerie, os anabatistas, os levellers e tantos outros, levantaram-se sucessivamente. A crueldade, atributo dos escravos, desonrou sua causa. A religião extraviou-os. Mas uma instituição que causou tantas calamidades, é uma instituição protetora?

Tudo o que vós dizeis a favor da hereditariedade, os antigos o diziam a favor da escravidão, e os ilotas faziam tremer Esparta, que os assassinava para contê-los, e Espártaco espantava Roma.

Tudo o que vós dizeis a favor da hereditariedade, os patrícios o diziam no senado, e, desde Cassius até César, as facções dilaceraram a República, e os plebeus, sempre sublevados contra a opressão, acabaram por aniquilar a liberdade.

Tudo o que vós dizeis a favor da hereditariedade, os colonos o dizem no Código negro, e os negros, sem parar, ensangüentam as colônias, e os horrores, que cometem, nos fazem sentir vergonha do homem, e detestar quase tanto os oprimidos quanto os opressores.

Não vós enganeis: esses crimes não são os da liberdade que reclama, mas da tirania que invade; a liberdade é apenas uma defesa, os privilégios são os agressores.

Enfim, quando a hereditariedade não trouxesse esses inconvenientes terríveis, haveria ainda por fazer contra esse sistema uma reflexão bem decisiva, é que ele não pode mais se levantar.

Os reis, os grandes, e aqueles que os defendem parecem ignorar o poder das idéias. Acostumados a que forças visíveis dominem invisíveis opiniões, não sentem que é a essas opiniões que essa força é devida. O hábito torna-os indiferentes ao milagre da autoridade. Vêem o movimento, mas como desconhecem o motor, a sociedade só lhes parece um grosseiro mecanismo. Tomam o poder por uma causa, enquanto que só é um efeito, e querem se servir do efeito contra a causa. 


\section{É, entretanto, às idéias somente que o império do mundo foi dado. São as idéias} que criam a força, tornando-se sentimentos, paixões ou entusiasmos. Formam-se e elaboram-se silenciosamente; reencontram-se e eletrizam-se pelo comércio dos indi-

\footnotetext{
${ }^{\mathrm{E}}$ Alguns homens, bastante esclarecidos para ter renunciado a combater as idéias pela força, acreditam ainda que se pode combatê-las por outras idéias, e imaginam em consequiência disso opor às verdades, que vêem como perigosas, os preconceitos, que lhes parecem salutares.É o grande recurso que indicam hoje aos Reis os escritores de seu partido. Quando o tempo destrói um preconceito, diz um dos mais notáveis dentre eles, um legislador sábio deve substitui-lo logo por outro.

É um erro. É preciso observar de início que as idéias são independentes dos homens. Como tudo na natureza, têm seu movimento, seu progresso, seus desenvolvimentos. Elas se formam das sensações, das experiências, dos acontecimentos, todas circunstâncias exteriores, que não nos são nem um pouco obedientes. É, pois, impossível estabelecer idéias que a força das coisas não conduz, fazer retrogradar aquelas que a força das coisas conduziu, ou de dar um valor àquelas cujo reino já passou.

As idéias que se quer assim criar por seu uso, estando sem nenhuma relação com aquelas que existem necessariamente, não podem se ligar a nada, nem estabelecer nenhuma raiz. Não formam de modo algum um todo, de tal sorte que, estando isoladas e sem apoio, não tardam em desaparecer. Assemelham-se a esse patriotismo de imitação, com a ajuda do qual acredita-se restabelecer a igualdade, entre soldados sem pátria e aqueles que defendem a sua.

Uma primeira desvantagem dos preconceitos é por conseqüência a de não poder ser empregados, quando deles se tem necessidade, e de faltar precisamente à época na qual seriam mais necessários. Um segundo inconveniente é a impossibilidade de dirigi-los e de prever seus resultados. Como é somente quebrando a cadeia do raciocínio, falseando o espírito, impedindo-o de caminhar, segundo a destinação, do princípio à conseqüência, que se dá um preconceito, não se pode jamais estar seguro que essa operação, que se lhe faz fazer, não se repetirá sem cessar, nem saber que conclusão extrairá desse preconceito aquele que a adotou. Tem-se que temer, pois, das idéias falsas, não somente seus resultados imediatos e naturais, que são ordinariamente funestos, mas tudo o que não parece minimamente delas resultar. Quem pode traçar o caminho que seguirá um espírito saído do caminho da razão? A verdade é uma, mas o erro é multiforme. Uma idéia falsa é uma impulsão desordenada cuja direção é incalculável. Dando essa impulsão, e pelo esforço mesmo que se necessitou fazer para dá-lo, colocase fora do estado de conduzi-la. Quem garantirá que um espírito, que não segue mais a direção justa, não se afastará de novo daquela que se quis como sua substituta? Por que extrairá ele da idéia, que fezse-lhe adotar, uma consequiência mais razoável, que aquela da qual fez-se-lhe extrair uma conseqüência falsa? Há, ao contrário, uma causa a mais, para que caia em um novo erro, pois disso fez um hábito. Os preconceitos por sua essência devem escapar, sem cessar, a quem quer empregá-los.

Quando muito, pode-se beneficiar daqueles que estão estabelecidos desde muito tempo, porque a experiência substituindo a lógica, aprende as consequiências que dela tiram aqueles que os admitem. Mas mesmo essa vantagem é bem efêmera, primeiro, porque os homens tendem sempre para a verdade, e que as idéias falsas perdem a cada dia terreno; segundo, porque os progressos da verdade, modificando essas idéias, destruindo seu conjunto, mudam indiretamente o efeito daquelas que não atacam ainda de frente.
} 
víduos. Assim sustentadas, completadas uma pela outra, logo precipitam-se, com uma impetuosidade irresistível.

Jamais uma idéia posta em circulação dela foi retirada ${ }^{\mathrm{E}}$. Jamais uma revolução fundada sobre uma idéia deixou de estabelecer seu império, a menos que a idéia não fosse completa. Então a revolução só era um sintoma anunciador de uma crise, e concluiu-se desde que a idéia completa voltou à carga ${ }^{\mathrm{F}}$.

A idéia de igualdade é uma idéia mãe, que jamais foi completamente expulsa do coração do homem. Ele misturou essa idéia em tudo. Não há uma religião nascente, que não a tenha consagrado, e foi sempre preciso que a fraude sacerdotal desnaturasse a instituição para afastá-la.

A origem do Estado social é um grande enigma, mas sua marcha é simples e uniforme. Ao sair da nuvem impenetrável, que cobre seu nascimento, vemos o gênero humano avançar em direção à igualdade, sobre os destroços das instituições de todo gênero .

Cada passo que deu nessa direção, foi sem retorno. Se algumas vezes acreditouse perceber um movimento retrógrado, é que se tomou o combate por um derrota, e a agitação da peleja por uma fuga.

\footnotetext{
F O que engana algumas vezes a respeito do sucesso das Revoluções, que produzem as idéias, é que se toma os acessórios pelo objetivo principal. Assim, por exemplo, crê-se que a Revolução da Inglaterra, em 1648, fracassou, porque a Realeza foi restabelecida. Mas não era a idéia da República, que tinha causado a Revolução, foi a idéia da liberdade religiosa. A República não era mais que um acessório, e o acessório fracassou. A idéia dominante, a repulsão da teocracia católica, triunfou plenamente.

${ }^{\mathrm{G}}$ Uma obra como esta não permite nem estabelecer, nem mesmo expor nenhum sistema. Mas há uma soberba história por fazer, sobre a marcha da sociedade, e se poderia demonstrar por mil provas o que dois grandes homens afirmaram, Um (Boulanger), para o passado, a partir das tradições da antigüidade, o outro (Condorcet) para o futuro, a partir de raciocínios abstratos. Vê-se, assim me parece, claramente, nos anais dos povos, a espécie humana se reunindo depois de uma transformação física, e sob uma teocracia esmagadora, colocar-se, por assim dizer, em marcha, por uma impulsão irresistível e desapercebida, e reconquistando lentamente e por terríveis perturbações todos os direitos que tinha perdido.

${ }^{\mathrm{H}}$ É preciso observar que é quase sempre por um grande mal que as Revoluções, que tendem ao bem da humanidade, operam, e que, mais a coisa a ser destruída é perniciosa, mais o mal da Revolução é cruel. O que destruiu a escravidão foram instituições que nos fizeram comprar esse fato bom por 15 séculos de abastardamento, e calamidades de todo o gênero. Mas a marcha da espécie humana,
} 
Vede, de início, castas proscritas, imundas, privadas da própria existência que parece inseparável de todo ser humano. Essa distinção odiosa encontra-se relegada a algumas tribos, semi destruídas, que não são mais nações.

Vede, a seguir, a escravidão ${ }^{H}$, menos revoltante que a proscrição das castas. Desapareceu sem retorno entre os povos civilizados.

O feudalismo, menos terrível que a escravidão, a sucedeu. Desmoronou da mesma forma, e irrevogavelmente.

Foi substituída pela nobreza. Hoje desaparece a nobreza, do seio do primeiro povo da Europa, e, no seio deste povo, ao menos, não mais se levantará.

Acredita-se poder recompor seu prestígio, decorando-a com o nome especioso de magistratura hereditária. É querer uma nova insurreição.

É preciso enfim ceder à necessidade que nos arrasta,é preciso não mais menosprezar a marcha da sociedade, não mais provocar, por vãos esforços, lutas sangrentas, não mais encontrar uma consolação ao marcar cada derrota por grandes males, não mais fazer os homens comprarem seus direitos por meio de crimes e de calamidades.

Recusei-me aos desenvolvimentos que exigiriam essas idéias, porque, repitoo, não escrevo contra nenhuma forma de governo, mas contra toda espécie de revo-

ao mesmo tempo retardada e favorecida por essas instituições, não foi desviada. Hoje, essas instituições caem, sem que a escravidão se levante. O flagelo passa, o bem fica. O que destruiu o feudalismo foram expedições insensatas e sangrentas, que despovoaram a mais bela parte da Europa. O que fez desaparecer a nobreza foi uma Revolução que, durante 15 meses, cobriu de cadáveres e de ruínas o império mais civilizado da terra. 
lução nova. Não convido nenhum estado monárquico a se tornar republicano, mas esconjuro os franceses -em nome de todos os interesses, de todos os cálculos, de todos os entusiasmos, em nome de todos os infortúnios à prevenir, de todas as feridas à fechar -a não revolucionar contra a República.

\section{CAPÍTULO VIII}

\section{Conclusão}

Esforcei-me nessas folhas em unir à República os homens que podem afastarse das lembranças dolorosas, dos cálculos que me parecem errôneos, uma vaidade que parece pueril, das esperanças cuja falsidade me é demonstrada. Acreditei no dever de todo amigo da liberdade de fazer ressaltar tudo o que pode unir a um governo de cuja existência a liberdade depende hoje. Que me seja permitido agora dirigirme ao próprio governo, e aos escritores que o defendem.

Ousaria lembrar ao primeiro, que o perigo mais iminente que o ameaça não vem de seus inimigos; vem de certos hábitos revolucionários, que são a destruição de todos os princípios, a perversão de todas as opiniões, e que pesam sobre a sociedade em massa, e sobre cada indivíduo em particular, em todas as horas e sob todas as formas.

Esses hábitos não são o resultado da tirania dos Decêmviros, mas da inabilidade das pessoas honestas. O que fez na França o maior mal, o mal mais difícil de reparar, foi precisamente a impaciência em fazer o bem.

Robespierre matava, mas não seduzia. A opinião que esmagava não estava extraviada. Permanecia no fundo dos corações, fortificada pelo horror mesmo da opressão. As pessoas honestas, ao contrário, ao seviciarem revolucionariamente os bandidos revolucionários, corromperam a opinião em sua fonte. Consagraram a ilegalidade, fazendo-a servir ao bem. Deveriam ter aproveitado todas as calamidades, resultantes do arbítrio, para gravar profundamente em todas as almas o ódio a ele, para nelas imprimir em traços indeléveis a convicção que o arbítrio só pode fazer o mal. Negligenciaram essa imensa vantagem, e por uma enganosa experiência, provaram que o arbítrio podia ser útil. 
É uma coisa infinitamente mais perigosa fazer a revolução a favor da virtude, do que a revolução a favor do crime.

Quando celerados violam as formas contra homens honestos, sabe-se que é um delito a mais. Ligamo-nos as formas, por sua violação mesmo; aprende-se em silêncio, e pela dor, a olhá-las como coisas sagradas, protetoras e conservadoras da ordem social. Mas quando homens honestos violam as formas contra os celerados, o povo não sabe mais onde se encontra; as formas e as leis se apresentam a ele como obstáculos à justiça. Contrai não sei qual hábito, constrói não sei qual teoria de arbítrio imparcial, que é a perturbação de todas as idéias; pois nos corpo político somente as formas são estáveis e que resistem aos homens. A própria base, isto é, a justiça, a virtude, podem ser desfiguradas. Seus nomes estão à mercê de quem quer empregálos. Robespierre pôde invocar a pátria, a liberdade, a moral, como Lanjuinais.

Quando o tirano fazia hinos, que tinham por refrão, nada de piedade, sangue, sangue, sabia-se que ele era um monstro, e o horror do sangue e o amor da piedade se fortificavam com a execração que ele inspirava: mas quando os homens probos e humanos, levados por um sentimento cego de indignação, adotaram canções nas quais se falava de fazer hecatombes, pôde-se acreditar que fazer hecatombes era uma ação louvável; assim, a justiça e a humanidade se enfraqueceram, pela confiança mesmo que se tinha pelos seus mais virtuosos defensores.

Resultou disso que um traço distintivo do caráter e da opinião do momento, um traço comum a todos os partidos, é que não se odeia o arbítrio por si mesmo, a primeira coisa que é necessario odiar em um país livre, mas somente tal e tal arbítrio, que contraria nossas impulsões ou nossos interesses. Enquanto essa disposição durar, nada será estável; a própria Constituição só será uma brochura, que cada partido poderá fechar a seu bel prazer.

Acredito ter provado que eu não desconheço o império das circunstâncias. Mas não se deve esquecer o quanto nesse gênero é fácil o abuso. Se não ficamos em guarda, haverá sempre circunstâncias para invocar contra os princípios. As facções andaram de circunstância em circunstância, sempre fora da lei, as vezes com intenções 
puras, as vezes com projetos pérfidos, pedindo eternamente grandes medidas, em nome do Povo, da liberdade, da pátria.

Cabe ao governo desenraizar esse hábito, que perpetuaria a revolução. Existem os meios, existe o interesse. Em relação a tudo o que a salvação pública exige, há duas maneiras de proceder, uma legal, outra arbitrária. Com o tempo, é sempre da primeira, mesmo que ela seja a mais lenta, que o governo tira o melhor proveito. Só ela pode lhe dar uma dignidade e uma força duráveis.

O uso do arbítrio desnatura os governos, e coloca-os na classe das facções. Os franceses, há seis anos, combatem-se com armas envenenadas, e se espantam em seguida de que seus combates são mortais, ao invés de serem decisivos. Eh! Antes, deponhais essas armas funestas! Entrai na observância das leis; e quando vos reconhecerdes mutuamente como homens que têm os mesmos direitos, e devem estar protegidos pelas mesmas formas, estareis já bem próximos; vos atacareis com bem menos encarniçamento; vossas derrotas serão menos sangrentas, vossas vitórias menos desonrosas. Enquanto considerardes o arbítrio como um instrumento que é preciso somente arrancar ao inimigo, para dele servir-vos, vosso inimigo se esforçará para vo-lo arrancar; e nunca a luta terminará, porque os meios arbitrários são inesgotáveis.

Hoje uma fonte espantosa do arbítrio está ainda aberta: é o momento de fechála. A maior parte das leis revolucionárias não estão revogadas. Entretanto, a obra de Robespierre lhe sobreviveu, ou os legisladores da França pensaram que os Decretos de um tal monstro, não tendo sido nunca legítimos, não merecem ser anulados? Esse silêncio pode ter efeitos terríveis; tremo, confesso-o, quando vejo, mesmo em relação a objetos de pouca importância, citar-se leis promulgadas entre o 31 de maio e o 9 de termidor. Apressai-vos em silenciá-las, que sua origem o exige. Dai a todas aquelas que são justas e necessárias uma nova sanção, e destruais as outras; até lá nenhum cidadão poderá dormir em paz. O gládio dos Decêmviros parecerá sempre suspenso sobre todas as cabeças. Sejais severos, mas sejais claros; sois bastante fortes para não ter necessidade de montar emboscadas. Distingais o que quereis conservar do que quereis rejeitar com um horror que vos honre, e que 
não haja mais em vosso código dessas leis ocultas que vagam nas trevas, que o inocente esquece, e que o celerado conserva para o momento de seu poder.

Quanto ao escritores que se consagram à defesa da República, que apreendam enfim a distinguir as funções do governo dos deveres do indivíduo.

O governo não pode entrar em todas as nuanças das opiniões. Ele não pode investigar, se, entre aqueles que não acreditam na República, existem amigos da liberdade. Ele deve olhar todos aqueles que não estão ligados à Constituição atual da França, senão como inimigos, ao menos como homens que é preciso vigiar.

O dever dos indivíduos é totalmente diferente. O governo só pode ver no conjunto, eles devem ver no detalhe. Ele não pode negligenciar nenhuma causa de precaução, eles devem agrupar todos os motivos de tolerância. Ele apenas pode empregar meios de repressão e de força; eles devem colocar em uso todos aqueles de raciocínio e persuasão.

No governo, a indulgência que aprecia todos os sistemas e concebe todas as opiniões, seria fraqueza. Nos particulares, a vigilância, que se antecipa a todos os complôs, e se impõe a todas os desvios, seria o rompimento de todo vínculo social.

É preciso que todos os dois permaneçam no caminho que lhes é próprio. Hoje que a República está estabelecida, o governo deve fazer tudo dobrar diante do sistema republicano; mas os amigos da liberdade devem tudo tentar para trazer de volta aqueles que o governo oprime. Cabe a eles distinguir as diferenças mais ligeiras, os mais imperceptíveis detalhes, em distinguir cuidadosamente aquele que odeia a liberdade daquele que apenas tem a infelicidade de nela não acreditar, aquele que nela não acredita daquele que teme a anarquia. Eles devem dividir o exército inimigo para nele reconhecer antigos aliados, ou nele obter novos trânsfugas. Eles devem ranger sob tantos estandartes diferentes, aqueles que diferentes motivos animam, o homem sensível subjugado por seus lamentos, o homem tímido enraivecido por seus medos, o filósofo seduzido por suas especulações, ou paralisados por suas dúvidas, o escravo do hábito, do amigo do repouso, aquele da ordem. Eles devem, enfim, apenas excluir e afastar os partidários degradados do Despotismo puro, ou os sectários ferozes do crime. 
Só esses são sem recurso; mas quem raciocina pode ser convencido, quem sente, suavizado, quem treme, tranqüilizado. Existem argumentos para todos os espíritos, tons para todos os corações, cálculos para todos os interesses.

Não imiteis esses satélites grosseiros que recrutam o exército que eles atacam, que apresentam a verdade de maneira a revoltar a razão, a liberdade de maneira a ferir a alma, a esperança, de maneira a inspirar o terror. Eles forçam todas as paixões, todos os sentimentos, e todas os medos, a se reunir contra o sistema que tem a infelicidade de ser defendido por eles. Acreditam ter merecido a República, e ao encontrá-la criaram-lhe um inimigo a mais.

Vós, com a oliveira em mãos, percorreis as planícies que eles devastaram. Vós descobrireis amigos, lá onde eles apenas procuram e encontram vítimas e cativos.

E vós, franceses, todos igualmente detestados pelos inimigos da República, seja por que a haveis sustentado com vossa coragem, ou sancionado com vossa presença, univos. Trata-se de se pronunciar entre o embrutecimento do homem e sua reabilitação, entre a superstição e as luzes, entre o século XI e o século XIX. Trata-se de mais ainda, mais, não para os homens, que preferem a morte a servidão, mas para essa almas egoísta e tímidas, que só pedem o repouso e que não sentem que o repouso sob o despotismo é só a impotência no desespero; trata-se de encontrar esse repouso na República ou de recomeçar, em sentido inverso, a rota terrível que a França percorreu, e de retornar à tirania, subindo o rio de sangue que se viu correr em nome da liberdade. 